\title{
New Neandertal remains from Cova Negra (Valencia, Spain)
}

\author{
J.L. Arsuaga ${ }^{\mathrm{a}, \mathrm{b}, *}$, V. Villaverde ${ }^{\mathrm{c}}$, R. Quam ${ }^{\mathrm{a}, \mathrm{d}}$, I. Martínez $^{\mathrm{a}, \mathrm{e}}$, \\ J.M. Carretero ${ }^{\mathrm{a}, \mathrm{f}}$, C. Lorenzo ${ }^{\mathrm{a}, \mathrm{g}}$, A. Gracia ${ }^{\mathrm{a}}$ \\ ${ }^{a}$ Centro de Investigación (UCM-ISCIII) de Evolución y Comportamiento Humanos, c/Sinesio, Delgado, 4, 28029 Madrid, Spain \\ ${ }^{\mathrm{b}}$ Dpto. Paleontología, Facultad de Ciencias Geológicas, Universidad Complutense de Madrid, Ciudad Universitaria, 28040 Madrid, Spain \\ ${ }^{\mathrm{c}}$ Departament de Prehistòria i Arqueología, Facultat de Geografia i Historia, Universitat de València, 46010 Valencia, Spain \\ - Department of Anthropology, State University of New York, Binghamton, New York 13902-6000, USA \\ ${ }^{\mathrm{e}}$ Departamento de Geología, Universidad de Alcalá, Edificio de Ciencias, Campus Universitario, 28871 Alcalá de Henares, Spain \\ ${ }^{\mathrm{f}}$ Laboratorio de Evolución Humana, Departamento de Ciencias Históricas y Geografía, Universidad de Burgos, \\ Edificio I+D+I, Plaza Misael Bañuelos s/n, 09001 Burgos, Spain \\ g Área de Prehistoria, Universitat Rovira i Virgili, Facultat de Lletres, Plaça Imperial Tarraco 1, 43005 Tarragona, Spain
}

\begin{abstract}
New Neandertal fossils from the Mousterian site of Cova Negra in the Valencia region of Spain are described, and a comprehensive study of the entire human fossil sample is provided. The new specimens significantly augment the sample of human remains from this site and make Cova Negra one of the richest human paleontological sites on the Iberian Peninsula. The new specimens include cranial and postcranial elements from immature individuals and provide an opportunity to study the ontogenetic appearance of adult Neandertal characteristics in this Pleistocene population. Children younger than 10 years of age constitute four of the seven minimum number of individuals in the sample, and this relative abundance of children at Cova Negra is similar that in to other Neandertal sites in Europe and southwest Asia. The recognition of diagnostic Neandertal features in several of the specimens, as well as their western European context and late Pleistocene age, suggests that all the human remains from Cova Negra represent Neandertals. The archaeological evidence from Cova Negra indicates sporadic, short-term occupations of the site, suggesting a high degree of mobility among Neandertals.
\end{abstract}

Keywords: Cova Negra; Neandertal; Cranial remains; Teeth; Postcranial remains; Ontogeny; Upper Pleistocene; Mousterian; Spain

\section{Introduction}

The site of Cova Negra contains one of the most complete late Pleistocene stratigraphic sequences in Mediterranean Spain, with archaeological levels dating between the Riss/Würm interglacial (OIS 5e) and the initial Würm III (OIS 3). Cova Negra is also one of the richest Middle Paleolithic sites on the Iberian Peninsula in terms of the number of Neandertal remains recovered, and it is one of several sites in Valencia that have yielded
Pleistocene human fossils (Arsuaga et al., 2001, 2002). The site is located on the left bank of the Albaida River in the municipality of Xàtiva in the region of Valencia (Fig. 1). The cave is situated some $17 \mathrm{~m}$ above the current level of the river and is characterized by a large entrance and contains some $500 \mathrm{~m}^{2}$ of surface area. Excavations have been carried out during three separate stages throughout the twentieth century.

In the early stage, three field seasons were conducted under the direction of G. Viñes between 1928 and 1933. During the course of excavations, an adult human parietal bone (Parietal I) was discovered. The first detailed study of this fossil (Fusté, 1953, 1958) emphasized its Neandertal affinities. In a later study, de Lumley (1973) regarded the Cova Negra specimen as middle Pleistocene in age, and, consequently, stressed its similarities with fossils that 


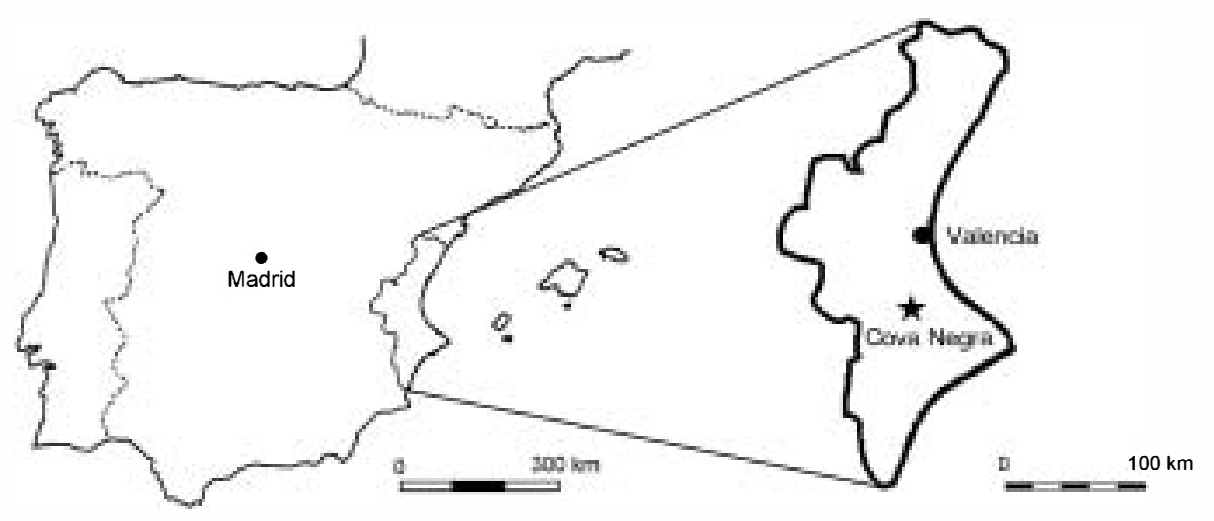

Fig. 1. Location of the Cova Negra site.

are today regarded as Homo heidelbergensis. However, the most recent study (Arsuaga et al., 1989a,b) again drew attention to the Neandertal affinities of the Cova Negra fossil.

Between 1950 and 1957, F. Jordá undertook five field seasons of excavation, opening 11 sectors of the cave (Fig. 2), focusing primarily on the external areas, and reaching a depth of approximately $5 \mathrm{~m}$ in some areas. New human fossils were also recovered, including a permanent upper central incisor, a child's right mandibular fragment, and an associated lower second deciduous molar. Following the statements of de Lumley (1973) regarding the parietal bone, Crusafont-Pairó et al. (1976) argued that these remains belonged to the so-called "Anteneandertal group." Nevertheless, the study by Arsuaga et al. (1989a,b) aligned them more closely with the Neandertals.

Finally, a third stage of excavations was directed by V. Villaverde between 1981 and 1991, with the aims of clarifying the stratigraphy and addressing new research paradigms developed in the intervening years after the previous excavations of Jordá. As a result of the most recent excavations, detailed studies have been published on the stratigraphy (Fumanal, 1986; Fumanal and Villaverde, 1988; Villaverde and Fumanal, 1990), exploitation of the fauna (Villaverde and Martínez Valle, 1992; Martínez Valle, 1996), analysis of microfaunal remains (Guillem Calatayud, 1996), and analysis of combustion zones (Soler Mayor, 1996), and thus a more thorough understanding of the nature of the occupation of the site has been possible (Villaverde et al., 1996).

In 1987, as a consequence of screening sediments that had fallen from the stratigraphic profiles from the excavations of the 1950s, new dental and cranial remains were found (Bermúdez de Castro, 1992; Arsuaga et al., 2001). However, it is not possible to assign a precise stratigraphic position other than "Mousterian sediments" for these specimens (Table 1) since the profile in this sector is more than $3 \mathrm{~m}$ in depth and includes levels $1-12$. At the same time, new cranial and postcranial remains were recognized among the museum collections of the material recovered during the excavations conducted in the 1950s. These include a complete femur, a complete radius, a distal femoral diaphyseal fragment, two metatarsals, and a distal fibular fragment (Arsuaga et al., 2001). Finally, in 1989, a second parietal bone (Parietal II) was found, along with a handwritten note dating to 1931 (during the excavations of Viñes), in a box deposited in the Museum of Prehistory in Valencia (Gracia et al., 1992).
The excavation method used at Cova Negra during the 1950 s consisted of removing artificially identified layers of sediment of between 5 and $20 \mathrm{~cm}$ in thickness. The sectors defined at the site varied in surface area, in some cases covering up to $40 \mathrm{~m}^{2}$ (Fig. 2). In general, scant attention was paid to the relationship between the archaeological material and the different stratigraphic units, complicating efforts to establish a firm correlation between the fossil remains recovered during these field seasons and the stratigraphic units defined during the excavations conducted in the 1980s. Nevertheless, accurately placing the Cova Negra remains within the stratigraphic profile and sector of the cave is fundamental to establishing their chronology and associations between different specimens.

Table 1 and Figure 3 list all the human fossil specimens and their assignment to a particular layer and sector within the site, as well as the proposed chronology based on the correlation with the stratigraphic sequence established after the most recent excavations (Fumanal, 1995; Villaverde, 1995; Fumanal and Villaverde, 1997). These correlations were established after considering the photographic documentation from the earlier excavations, the information provided in the excavation diary and field notes, and the present-day detailed knowledge of the general tendencies of the dips in the stratigraphy in the cave along its two major axes. In the case of Parietal II, found by Viñes in 1931 in the red sediments in his layer 12, the existence of a markedly red-colored layer (current layer VIII) widely distributed throughout the cave, allows us to suggest a precise stratigraphic assignment. Thus, all of the human remains from Cova Negra derive from Mousterian deposits and span the time range from OIS $5 b-3$.

Here we provide a detailed description of the new cranial and postcranial fossils and a comprehensive study of the entire human fossil sample from Cova Negra. For comparative purposes, we have relied on personal observations and measurements, as well as published descriptions of immature late Pleistocene $\mathrm{Ne}$ andertal and early modern human specimens from Europe and southwestern Asia. For the postcranial remains, we have relied on a skeletal sample of 22 modern children between the ages of two and six years at death that derive from the excavations of the Dominican Monastery of San Pablo in Burgos, Spain, and date to the late Middle Ages (thirteenth to fifteenth century). In addition, a small sample of medieval individuals from the 


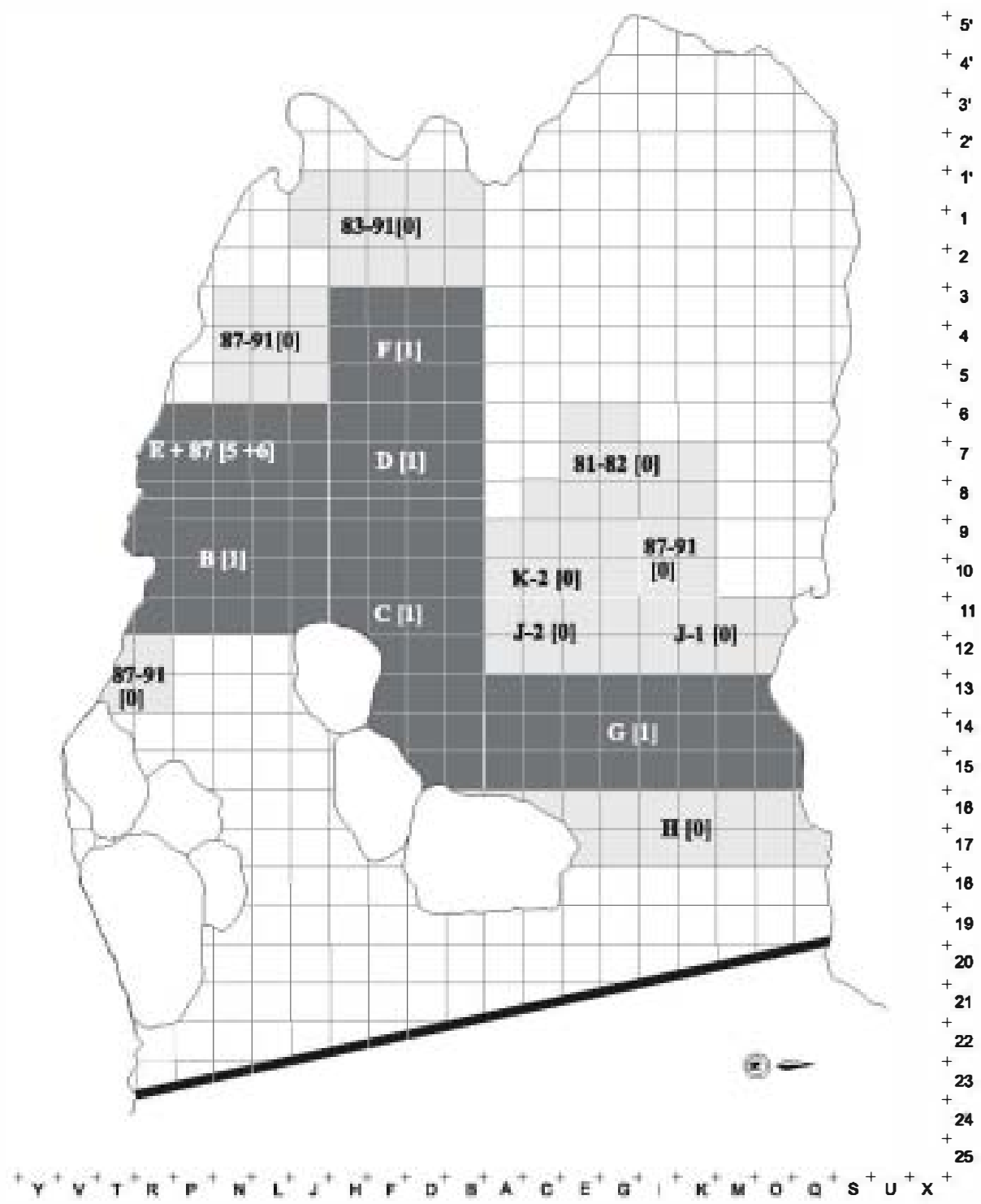

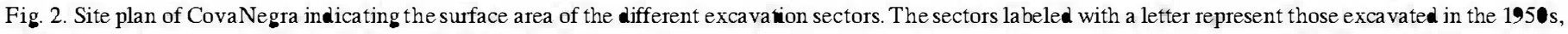

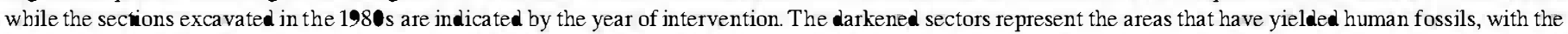

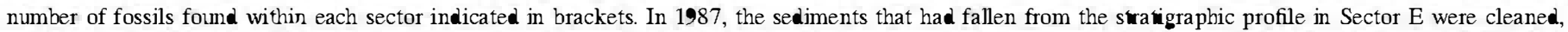

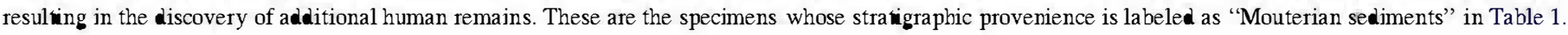

Mønastery $\bullet$ S San Ildeføns in Segøvia, Spain, were als measured to estimate the age at death for the metatarsals. Age at death in all of these medieval individuals was established by radiøgraphic examination of the crown and root formation and comparison with standards in living humans (Moorrees et al., 1963; Anderson et al., 1976; Hillson, 1996). Nevertheless, we acknowledge that our use of the medieval sample as the only modern human reference population limits the discussion of ecøge graphic, specific, and/or populational variation. Finally, the cross-sectional properties of the long bones were computed using AUTOCAD version 2002.

\section{Stratigraphy, dating, and archaeological context}

The stratigraphic sequence from Cova Negra comprises 15 levels that span the late Pleistocene, representing six sedimentary phases (Fumanal, 1995; Villaverde, 1995; Fumanal and Villaverde, 1997), which are briefly described below. The thermoluminensce (TL) dates prøvided for levels 4, 12, and 15 were performed at the Sedimentoløy Laboratory at Warsaw University (Poland) by H. Proszynska-Børdas and W. Stranska-Proszynska.

Cova Negra Phase A was warm and humid. The Albaida River introduced fluvial sediments int the cave, giving rise to the formation of levels of tufts with calcium-carbonate precipitations forming over plant elements. Archaeløgically sterile, this phase coincides with level 15 , and TL dating provides an age of $117 \pm 17$ thøusand years. This phase, then, correlates with the Riss-Würm (OIS 5e).

Cova Negra Phase B begins coel and very humid and culminates with rigorous climatic conditions. These weathering processes contribute to a fragmentation of the cave walls 


\begin{tabular}{|c|c|c|c|c|c|}
\hline Inventory no. & Specimen & Original provenience & Assigned stratigraphic level & Chronology & Field season \\
\hline \multicolumn{6}{|l|}{ Cranial remains } \\
\hline Parietal I & Adult right parietal & "Eswato Medio Interior" & $4-8$ & OIS 3 or 4 & 193 \\
\hline Parietal II & Adolescent right parietal & Level 12 "Tierras rojas" & 8 & OIS 4 & 1931 \\
\hline $\mathrm{CN} 42164 \mathrm{a}$ & Inmature left frontal fragment & Level 18, Sector E & $5-7$ & OIS 4 & 1951 \\
\hline $\mathrm{CN} 42164 \mathrm{~b}$ & Inmature left parietal fragment & Level 18 , Sector $\mathrm{E}$ & $5-7$ & OIS 4 & 1951 \\
\hline $\mathrm{CN} 4217 \bullet-731 \bullet$ & Inmature left parietal fragment & Level 9, Sector E & $3-5$ & OIS $4-3$ & 1951 \\
\hline CN $4217 \bullet-7311$ & Left parietal fragment & Level 9, Sector E & $3-5$ & OIS $4-3$ & 1951 \\
\hline $\mathrm{CN} 4217 \bullet-7312$ & Immature occipital fragment & Level 9 , Sector E & $3-5$ & OIS $4-3$ & 1951 \\
\hline $\mathrm{CN} 4217 \bullet-7313$ & Right parietal fragment & Level 9, Sector E & $3-5$ & OIS $4-3$ & 1951 \\
\hline $\mathrm{CN} 42174$ & Right parietal fragment ( 5 fragments) & Mousterian sediments & Mousterian sediments & $?$ & 1987 \\
\hline $\mathrm{CN} 42174 \mathrm{a}$ & Immature left parietal fragment & Mousterian sediments & Mousterian sediments & $?$ & 1987 \\
\hline $\mathrm{CN} 42174 \mathrm{~b}$ & Inmature left parietal fragment ( 3 fragments) & Mousterian sediments & Mousterian sediments & $?$ & 1987 \\
\hline $\mathrm{CN} 7755$ & Inmature right mandibular fragment & Level 33, Sector $\mathbf{D E}$ & $11-12$ & OIS $5 b$ & 1951 \\
\hline \multicolumn{6}{|l|}{ Dental remains } \\
\hline $\mathrm{CN} 42175$ & Crown of left $\mathbf{P}^{4}$ & Mousterian sediments & Mousterian sediments & $?$ & 1987 \\
\hline $\mathrm{CN} 42175$ & Crown of left $\mathrm{dm}^{2}$ & Mousterian sediments & Mousterian sediments & $?$ & 1987 \\
\hline $\mathrm{CN} 42175$ & Crown of left $\mathbf{M}^{1}$ & Mousterian sediments & Mousterian sediments & $?$ & 1987 \\
\hline $\mathrm{CN} 7755$ & Left $\mathrm{dm}_{2}$ & Level 33, Sector $\mathbf{D E}$ & $11-12$ & OIS $5 b$ & 1951 \\
\hline CN 7856 & Young adult right $\mathrm{I}^{1}$ & Level 3, Sector F & $1-2$ & OIS 3 & 1953 \\
\hline \multicolumn{6}{|l|}{ Postcranial remains } \\
\hline $\mathrm{CN} 42165$ & Inmature right radius & Level 20, Sector E & $6-7$ & OIS 4 & 1951 \\
\hline CN 42166 & Inmature right fourth metatarsal & Level 11, Sector E & $3-5$ & OIS $4-3$ & 1951 \\
\hline CN 42167 & Inmature right third metatarsal & Level 13 , Sector $\mathrm{E}$ & $3-5$ & OIS $4-3$ & 1951 \\
\hline CN 42168 & Distal $2 / 3$ of an immature right femur & Level 3, Sector G & $2-3$ & OIS 3 & 1953 \\
\hline $\mathrm{CN} 42169$ & Proximal $1 B$ of an immature right femur & Level 3, Sector G & $2-3$ & OIS 3 & 1953 \\
\hline $\mathrm{CN} 42171$ & Distal $1 B$ of an immature fibula & Level 17 , Sector $\mathbf{B}$ & $7-8$ & OIS 3 & 1950 \\
\hline $\mathrm{CN} 42318$ & Distal $1 / 3$ of an adolescent right femoral diaphysis & Level 13, Sector B & $6-7$ & OIS 4 & 1950 \\
\hline
\end{tabular}

and the presence of indigenous (i.e., limestone) elements in the sedimentary fill. This phase coincides with levels 14 and 13 and corresponds to Würm I (OIS 5d-b).

Cova Negra Phase $C$ was warm with seasonal rainfall, allowing søil formation. This phase corresponds to the Würm I-I interstadial (OIS 5a) and coincides with level 12. Tw• TL dates have been $\bullet$ btained that provide unusually early ages of $96 \pm 14$ and $107 \pm 16$ thøusand years.

Sedimentary evidence indicates that Cova Negra Phase D was a cold stage, including processes of gelifraction, which alternate with milder pulses. This phase corresponds to Würm $\mathbf{I}$ (OIS 4) and correlates with levels 11-5.

Cova Negra Phase E was warm and characterized by seasøal precipitations, which again stimulated søil formation. This phase is identified in the west sector of level 4 and

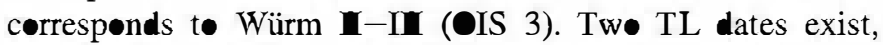
providing ages of $53 \pm 8$ and $50 \pm 8$ thøusand years.

Cova Negra Phase F was the final one at the site and is capped by a level of disturbed sediments of variable thickness. This phase is characterized by cold and dry climatic conditions, which are manifested by the presence of fine-grained sediments. Phase F coincides with levels $3-1$ documented in the western sector of the cave. Although repeated attempts to date levels 2 and 3 by ${ }^{14} \mathrm{C}$ AMS and U-Series analysis have been unsuccessful, this phase most likely corresponds to the initial Würm II based on its relative position within the stratigraphic sequence.
The Mousterian lithic industry from the different levels in Cova Negra is quite uniform, and is overwhelmingly dominated by side scrapers. The variation in reduction sequences and typølogical categøries of the assemblage, in addition to the increased or decreased presence of certain types of scrapers, makes it possible to identify a stonetool industry in the lower levels that easily conforms typløgically to the Quina variant of the Møusterian, with the notable presence of limaces, canted side scrapers, double side scrapers with a thinned back, and Tayac points, as well as denticulates and notched pieces (Phases B and C, levels 14-12). An increase in the use of the Levalløis technique, assøciated with a loss of typøløgical diversification, with a greater dominance of side scrapers and flat supports, allows us t• identify the existence of a Paracharentian variant during OIS 5b (Phase D, level 11). This is followed by a thick packet of sediments with a stone-tøol industry ascribed to the Quina variant (Phase D, levels 10-6), but of a larger size than that seen in the lower levels. Toward the end of IS 4 and during IS 3, a Paracharentian industial variant reappears, again showing an abundance of side scrapers and a moderate presence of the Levallois technique (Phases D and E, levels 5-4). Finally, the stone tools in the upper levels (Phase F, levels 3-1) alsø correspønd to a Paracharentian variant of the Møusterian, similar to the preceding level 4 in bøth the high percentage $\bullet$ side scrapers and moderate presence $\bullet$ the Levalløis technique. 


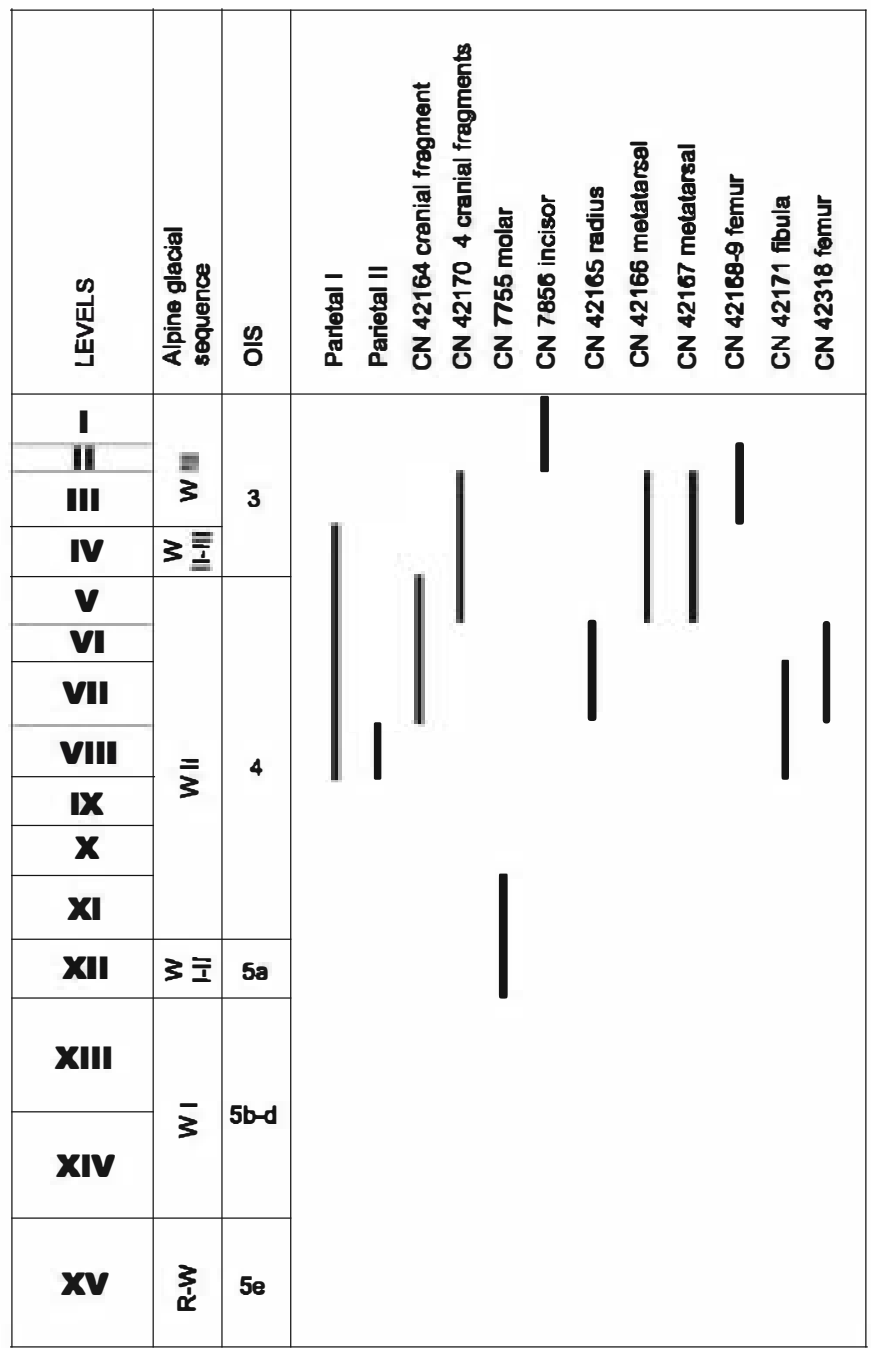

Fig. 3. Stratigraphic position of the Cova Negra human remains.

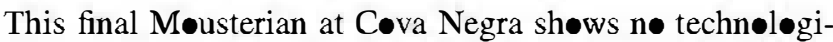
cal changes toward the Upper Pale lithic that would allow us to speak of a ransitional industry or even of an Upper Pale lithic influence. In fact, the late Mousterian from Cova Negra is remarkably conservative, being dominate by side scrapers and a low laminar component. The few Upper Paleølithic implements, which derive from the uppermost level of disturbed sediments, correspønd tø later phases and indicate that the sediments in Cova Negra do not preserve evidence of the earliest Upper Pale lithic stages and the arrival of modern humans in this region of the Iberian Peninsula.

\section{Cranial remains}

Although the state of preservation of most of the new cra-

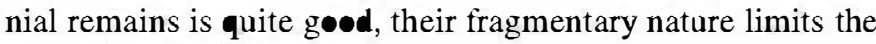
collection of metric data.

\section{Parietal II (Figs. 4, 5)}

Parietal 1 from Cova Negra represents approximately the central/pøsterior half $\bullet$ a right parietal bøne, with a maximum length of $97 \mathrm{~mm}$ (Fig. 4). Only $35 \mathrm{~mm}$ of the sagittal suture are preserved, corresponding to the region of the parietal foramen. The sagittal suture in the region of lambda is irregular, which makes it difficult to precisely locate this craniømetric point and suggests the existence of a lambdoidal ossicle. Bøth the external and the endocranial surfaces show significant taphonømic alterations, with an almost complete loss $\bullet$ both tables and a consequent reduction in bone thickness. The maximum bone thickness, $6.2 \mathrm{~mm}$, is bbtained in the anterior region of the fragment, at the level of the fissure of Rølando, and the thickness at the parietal protuberance is $5.5 \mathrm{~mm}$.

Due to the taphonomic alteration of the endocranial table, only a few vascular impressions can be discerned on Parietal I. It is pøssible to identify part of the course of the lambdoidal branch of the meningeal system, with one of its derivatives, and the corresponding portion of the superiør sagittal sulcus, which runs parallel to the preserved segment of the sagittal suture.

Despite the $\bullet$ bviøus difficulties, given that $\bullet$ nly a part $\bullet$ the sagittal suture is preserved, we believe it is possible to attribute a subcircular profile in norma occipitalis to the parietal vault $\bullet$ which Parietal $\mathbf{I}$ formed a part (Fig. 5). The regularity of the curvatures in the preserved fragment and the absence of a distinct parietal protuberance lead us to this conclusion since these are traits that characterize the subcircular pattern in Neandertal parietal vaults. In this regard, the adolescent Parietal I is similar t• the adult Parietal I from Cøva Negra (Arsuaga et al., 1989a,b).

\section{Frontal and parietal fragments (CN 42164 a, b) (Fig. 6)}

These tw fragments were assigned the same specimen number (CN 42164) in the field, but n॰ anat mical connection exists between them, and it is not clear if they represent the same individual. Given this reservation, we have labelled the frontal fragment CN 42164a and the parietal fragment CN 42164b.

Specimen CN 42164a is a left fragment of frontal squama that does not reach the midsagittal plane. Its maximum dimensions are $43.7 \mathrm{~mm}$ in the sagittal plane and $34.3 \mathrm{~mm}$ in the cor-nal plane. Part of the maxillary process is preserved on the left side, as well as $5.3 \mathrm{~mm}$ of the border of the orbit. On the most medial part of the maxillary process, an ethmøidfrontal air cell $(5.5 \mathrm{~mm} \times 2.8 \mathrm{~mm} \times 1.3 \mathrm{~mm})$ can be seen. The bone thickness on the frontal squama at the most corønal point preserved (on the natural fracture) is $3.6 \mathrm{~mm}$. In the region corresponding to the supraorbital torus, a change in color can be seen due to the elevated poresity in this area; the maximum thickness is $7.1 \mathrm{~mm}$. On the most medial part $\bullet$ the in-

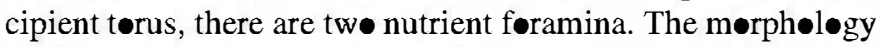
of the preserved squama is evenly convex, and, unlike modern immature specimens, there is n appreciable lateral protuberance. On the internal face, several cerebral impressions are

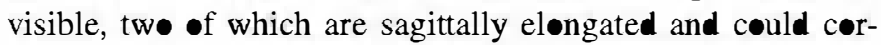
respond to part of the first and second frontal cerebral convelutions. 


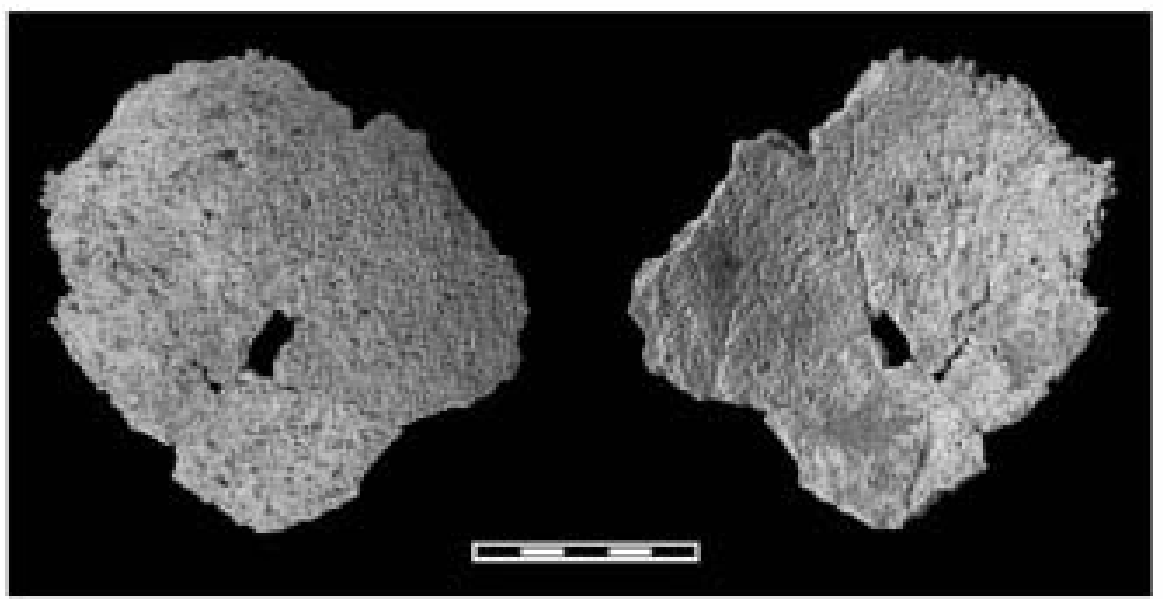

Fig. 4. The Cova Negra Parietal II in external (left) and endocranial (right) views. The sagittal suture is visible along the superior margin of the specimen. Scale $=5 \mathrm{~cm}$.

Specimen CN $42164 \mathrm{~b}$ is a parietal fragment of indeterminate side with a rectangular shape and maximum dimensions of $22.5 \mathrm{~mm}$ by $21.2 \mathrm{~mm}$. On the external face, the presence of a fine striation leads us to situate it in the region of the parietal protuberance. Bone-thickness values vary between $3.3 \mathrm{~mm}$ and $5.1 \mathrm{~mm}$.

\section{Parietal fragment (CN 42170-7310) (Fig. 7A, F)}

This is a fragment of the lambdoidal region of a left parietal, lacking lambda and asterion. Externally, the maximum dimensions are $56.8 \mathrm{~mm}$ in the sagittal direction and $44.1 \mathrm{~mm}$ along the lambdoidal suture. In its lower half, an elongated, shalløw depression can be observed parallel to the lambdoidal suture, which could be interpreted as part of the paralambdoidal depression. The thickness of the bone along the suture is $4.2 \mathrm{~mm}$ and reaches $4.5 \mathrm{~mm}$ in the region of the parietal protuberance.
Both the external and endocranial surfaces are well preserved. On the endocranial face, in addition to several impressions, a small part of the obelic branch of the middle meningeal artery, as well as secondary grøoves from the lambdoidal branch, can be seen. On the external face, striations are visible radiating from the parietal protuberance; there are nø indications -f synostosis aløng the preserved length of the lambdoidal suture. This fragment articulates along the lambdoidal suture with the occipital fragment CN 42170-7312 (Fig. 7).

Parietal fragment (CN 42170-7311) (Fig. 7D, G)

This specimen is a left parietal fragment preserving part of the coronal suture and corresponding to the lower third of the bone, although it doesn't reach pterion. The length of the preserved suture is $15.4 \mathrm{~mm}$, while the sagittal and coronal lengths are $56 \mathrm{~mm}$ and $43.5 \mathrm{~mm}$, respectively. Bøne thickness

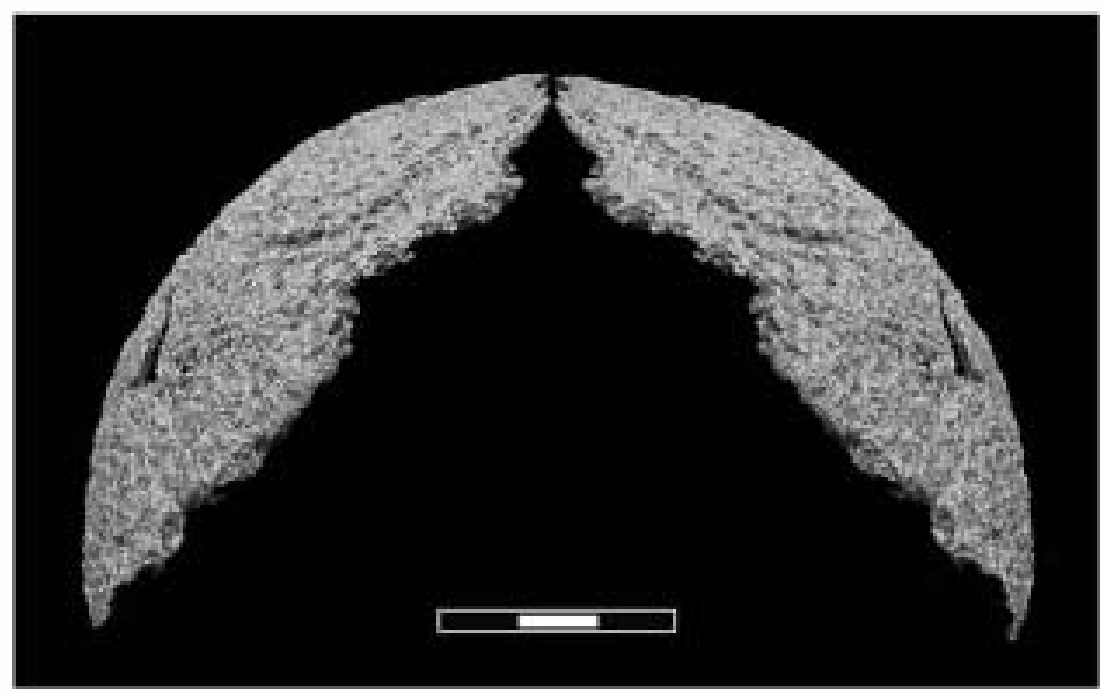

Fig. 5. Reconsuction of the parietal vault in Cova Negra Parietal II by mirror-imaging showing the subcircular profile of the specimen in norma posterior. Scale $=3 \mathrm{~cm}$. 


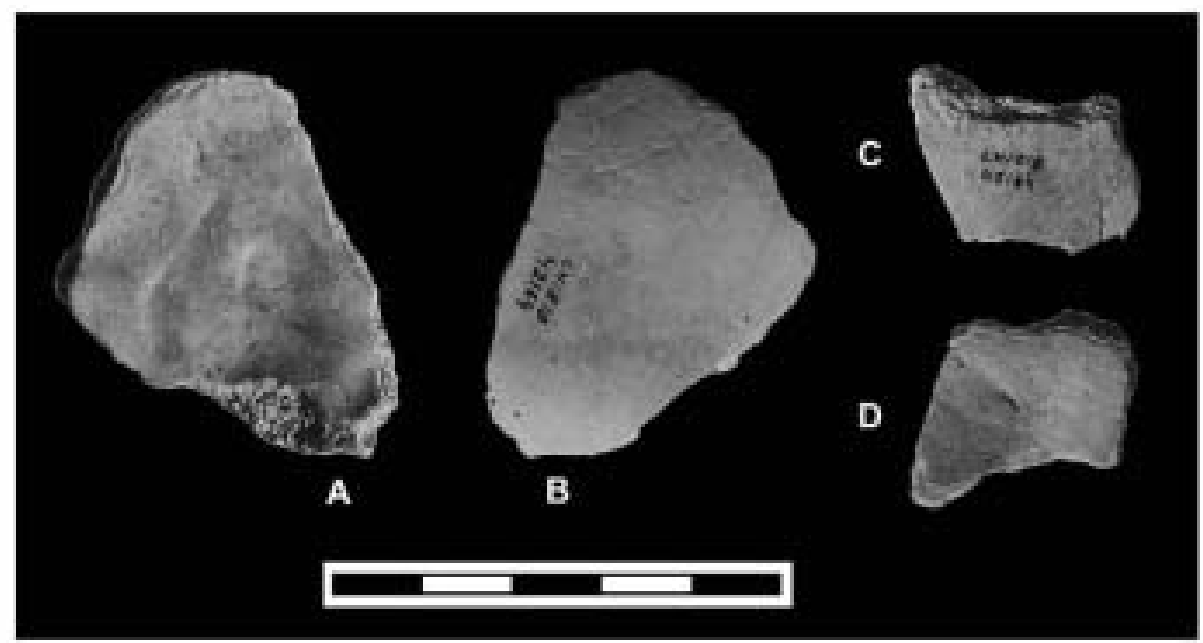

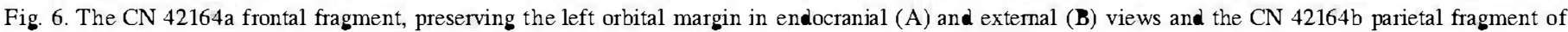
indeterminate side in external (C) and endocranial (D) views. Scale $=5 \mathrm{~cm}$.

along the suture varies between $3.5 \mathrm{~mm}$ and $2.9 \mathrm{~mm}$, while the rest of the bone presents similar values.

On the external table, the temporal lines can be discerned along part $\bullet$ their length, while the endocranial surface presents marked impressions and the sulcus for Breschet's sinus which measures $9.5 \mathrm{~mm}$ wide. The bregmatic and •belic branches of the middle meningeal artery can alsø be identified.

Occipital fragment (CN 42170-7312) (Figs. 7B, E, 8)

This specimen is a left occipital fragment preserving $11.5 \mathrm{~mm}$ of the lambdoidal suture, with maximum diameters -f $49.7 \mathrm{~mm}$ by $35 \mathrm{~mm}$. The fragment doesn't reach the midline, and only the occipital plane is represented. The thickness
- the bone at the suture is $4.6 \mathrm{~mm}$, while near the center $\bullet$ the -ccipital squama, the fragment is almost $5 \mathrm{~mm}$ thick. The endocranial surface is deteriorated at the level of the occipital torus, and there are no races of the transverse sinus, which may have passed below the level at which the bone was broken. This fragment articulates along the lambdoidal suture with

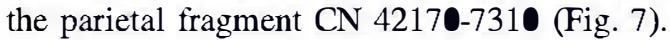

On the medialmost portion of the occipital fragment, near the fracture line, there is a marked thickening of the bone, indicating the presence of an occipital torus. Abøve this, there is an irregularly shaped and well-defined depressed area, which clearly corresponds to the lateral portion of the suprainiac fossa (Fig. 8). Below the torus, a concavity for the $\mathbf{m}$. semispinal is capitis can be discerned.

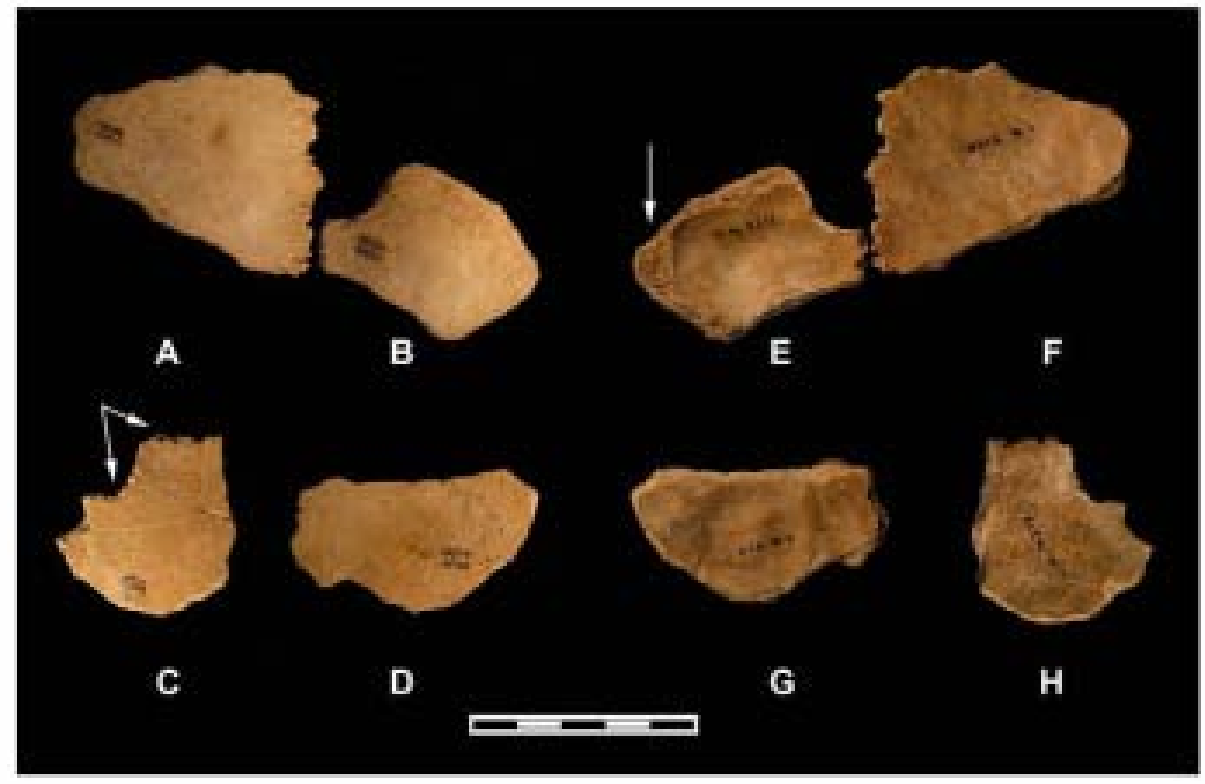

Fig. 7. The CN 4217 series of cranial fragments. The lambdoidal region of a left parietal CN $4217-7310$ in external (A) and endocranial (F) views. The left parietal fragment CN 4217-7311 in external (D) and endocranial (G) views. The occipital fragment CN 4217-7312 in external (B) and endocranial (E) views. Note the marked thickening of bone, indicang the presence of a n occipital torus (arrow in E). This specimen articulates with CN 4217-7310 along the lambioidal suture. The right parietal fragment $\mathrm{CN}$ 4217-7313 in external (C) and endocranial $(\mathbf{H})$ views. Note the presence of a cranial suture along the superior and posterior margin (arrows in C). Scale $=5 \mathrm{~cm}$. 
The morphology of the suprainiac fossa in the Cova Negra -ccipital fragment CN 42170-7312 is similar to the condition repørted t• characterize the very yøung Neandertal individuals frøm Dederiyeh (2 yr), Røc de Marsal (3 yr), La Chaise Suard, Engis 2 (6-7 yr), and La Quina H18 (8 yr) (Hublin, 1980; Madre-Dupøuy, 1992; Akazawa and Muhesen, 2003), indicating that this feature appears at a very early developmental age in Neandertals. At the same time, this anatomical structure is absent in the early modern human children Qafzeh 12 (3-4 yr) and Qafzeh 10 (6 yr), as well as the Gravettian specimen from the nearby site of Malladetes (5-7 yr) (Tillier, 1999; Arsuaga et al., 2002). Tillier (1999) reported the presence $\bullet$ the $\bullet$ utline $\bullet$ a suprainiac fossa in the sømewhat $\bullet$ lder (12-13 yr) Qafzeh 11 individual, but our examination of a cast of this specimen does nøt support this contention.

While the suprainiac fossa has been cited as a derived Neandertal feature (Hublin, 1978, Arsuaga et al., 1997), it has als been decumented in the African middle Pleistøcene specimen Eyasi 1 (Trinkaus, 2004), as well as the Magdalenian modern human specimen from Rønd-du-Barry (Trinkaus, 2002). Thus, it is apparently not restricted to fossils representing the Neandertal lineage, but it does occur at a much higher frequency among these høminids. Given the Mousterian archae $\bullet$ gical context for the Cova Negra specimen, as well as its late Pleistocene age and western European ge graphic

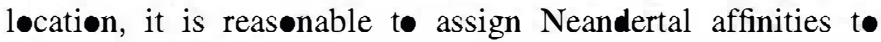
this $\bullet$ ccipital fragment.

\section{Parietal fragment (CN 42170-7313) (Fig. 7C, H)}

This is a right parietal fragment preserved for $42.9 \mathrm{~mm}$ along one of the cranial sutures. This suture changes direction along its length, with an angle that indicates that the fragment

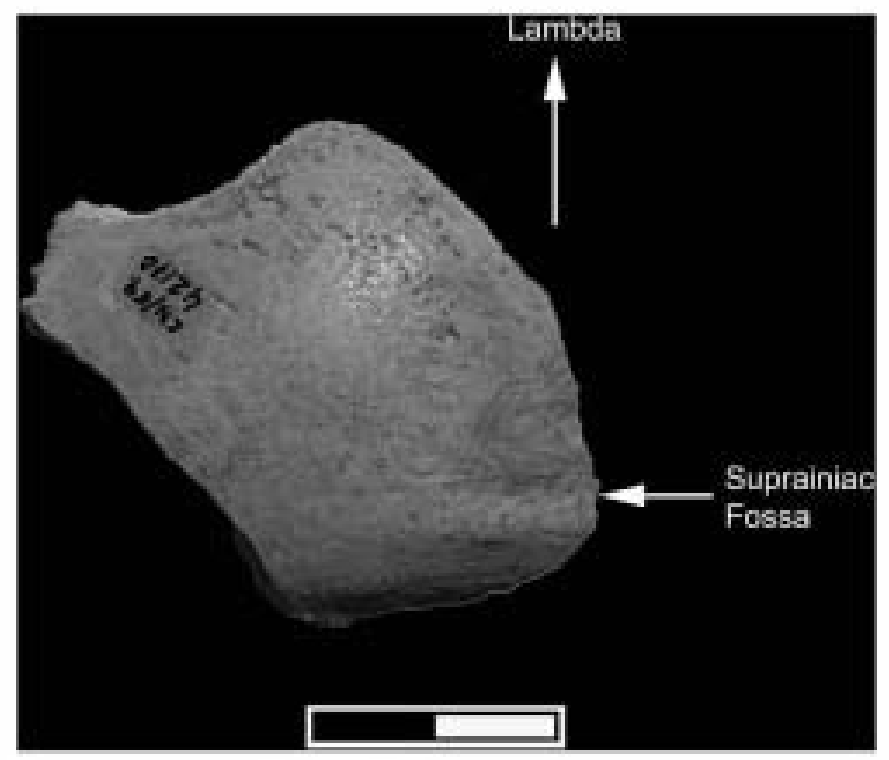

Fig. 8. Detail of the CN 4217- 7312 occipital fragment showing the presence of the suprainiac fossa. A portion of the lambdoidal suture is preserved on the left. Scale $=2 \mathrm{~cm}$. could correspond to the region of either lambda or asterion. Although neither the external nor endocranial surfaces $\bullet$ fer clear indicat $\bullet$ r the anatømical pøsition of the fragment, the presence on the endocranial surface of a light sulcus along the length of the shorter suture segment leads us to believe that it correspønds to the sagittal suture (with the sulcus corresponding to the superior sagittal sulcus) and that the fragment belongs to the region of lambda, which is preserved on the fragment. The dimensions of the fragment are $42.9 \mathrm{~mm}$ along the suture and $37.2 \mathrm{~mm}$ perpendicular to this. Bøne thickness aløng the suture varies between $4.4 \mathrm{~mm}$ and $3.2 \mathrm{~mm}$, and at the furthest pøint on the bone away from the suture it reaches $4.1 \mathrm{~mm}$.

\section{Parietal fragment (CN 42174) (Fig. 9)}

This specimen is part of a right parietal formed by five small fragments. The maximum coronal length of the fragment is $59.8 \mathrm{~mm}$ and the maximum sagittal length reaches $30.5 \mathrm{~mm}$. Part of the lambdoidal suture is preserved for a length of $22.3 \mathrm{~mm}$; asterion and a small portion of the parietomastoid regiøn (18.5 mm løng) are als• preserved. Thickness at asterion is $4 \mathrm{~mm}$; along the lambdoidal suture, the fragment reaches a thickness of $3.1 \mathrm{~mm}$, and toward the parietal protuberance it measures only $1.8 \mathrm{~mm}$. On the external surface, a slight paralambdoidal sulcus can be discerned, as can the posterior part of the inferior temporal line. On the endocranial face, several cerebral impressions can be seen, as well as the vascular grøoves corresponding to the lambdoidal branch of the middle meningeal artery, which enter the parietal frøm the parietømastøid suture.

\section{Parietal fragment (CN 42174a) (Fig. 10)}

This is a fragment frøm the lambdoidal regiøn $\bullet$ a left parietal, with dimensions $\bullet 38.7 \mathrm{~mm}$ in the sagittal direction and $33.3 \mathrm{~mm}$ in the coronal direction. It preserves $22.7 \mathrm{~mm} \bullet$ of the sagittal suture and $12.4 \mathrm{~mm}$ of the lambdoidal suture, including lambda. The thickness values are $4.2 \mathrm{~mm}$ at the sagittal suture, $5.1 \mathrm{~mm}$ at lambda, $4.4 \mathrm{~mm}$ at the lambdoidal suture, and $4.0 \mathrm{~mm}$ near the parietal protuberance. Bøth the ectocranial and endocranial surfaces are well preserved, and on the latter, a circular depression (Pacchioni's granulation) near lambda stands out, as does the impression for the sagittal sinus along the preserved length of the sagittal suture.

\section{Parietal fragment (CN 42174b) (Fig. 11)}

This is a fragment $\bullet$ the central part $\bullet$ a right parietal, between the region of the parietal protuberance and the sagittal suture, but preserving neither $\bullet$ these anatøical structures. It is composed of three fragments and their maximum dimensions in the coronal and sagittal directions are $58.8 \mathrm{~mm}$ and $33.7 \mathrm{~mm}$, respectively. The maximum thickness, near the region of the parietal protuberance, is $5.3 \mathrm{~mm}$, and the minimum thickness, in the region nearest to the sagittal suture is $3.8 \mathrm{~mm}$. On the external face, tw semicircular depressions $(18.6 \mathrm{~mm}$ apart $)$ stand ๑ut, and have clearly collapsed the external table of the bone. 


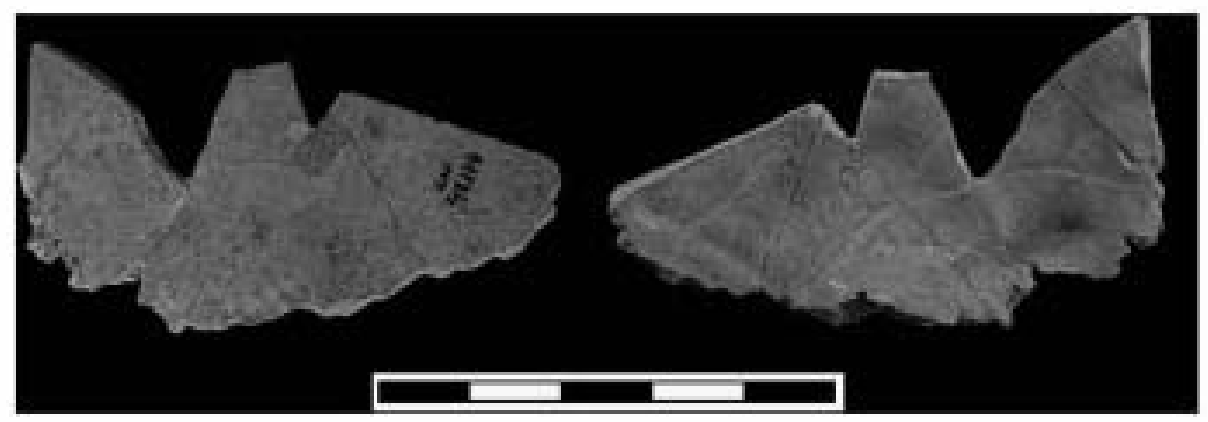

Fig. 9. Five fragments that constitute part of a right parietal CN 42174 in external (left) and endocranial (right) views. Scale $=5 \mathrm{~cm}$.

The diameter $\bullet$ the løwer depression is $2.8 \mathrm{~mm}$. The upper depression is actually composed of tw smaller depressions (each measuring $2.7 \mathrm{~mm}$ ) in the form of a figure eight. There are n॰ similar depressions on the endocranial surface.

The morphøløgy and dimensions of the depressions on the external surface indicate that they may represent marks produced by the canines of a small carnivore. The separation between the canines and the diameter of the depressions discount camivores the size of a fox or lynx, as well as small mustelids, such as a sable, but they are compatible with the values for badgers (N. García, personal communication), whose contact with these bones must have been postmortem.

\section{Age at death and minimum number of individuals}

The age at death $\bullet$ the cranial remains is difficult t• establish with certainty, but a relative developmental stage can be established within the sample based on the bone thickness. Despite the fragmentary nature of most of the fossils, it is pøssible tø measure the bone thickness at the parietal protuberance in many specimens.

The thickness at the parietal protuberance in the adult specimen Parietal $I$ is the largest in the sample and is close to the upper limit among adult Neandertals (Arsuaga et al., 1989a,b). All of the remaining Cova Negra cranial remains that can be compared show smaller values for the thickness at the parietal protuberance compared with the Parietal I specimen.

The CN 42174 specimen is thinner than any of the other Cova Negra specimens. The value for this specimen $(1.8 \mathrm{~mm})$ is well below the mean value in a sample of Neandertal children (Madre-Dupøuy, 1992) and toward the lower end of the range of variation (mean $=3.4 \mathrm{~mm}$; s.d. $=1.3$; range $=$ $1.3-4.5 \mathrm{~mm} ; n=5$ ). The rest of the Cova Negra specimens show a range of thickness values $(4.0-5.5 \mathrm{~mm})$ that $\bullet$ verlaps the upper limit of the immature Neandertals and the lower limit of a sample of Neandertal adults (mean $=8.3 \mathrm{~mm}$;

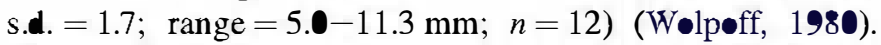
Among these specimens, the value for Parietal $\mathbf{m}$ is the largest. As mentioned previøusly, this specimen has suffered postmortem alteration to the external table, and the bone thickness shøuld be considered to represent a minimum value. This sug-

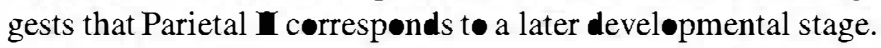

Thus, in addition to the adult specimen Parietal I (Arsuaga et al., 1989a,b), three relative developmental stages can be established within the cranial remains. The earliest stage is represented by $\mathrm{CN} 42174$ and the latest by Parietal II. Based on the growth trajectory of parietal thickness (Trinkaus, 2002), it is pøssible to tentatively assign rough age categøries for søme of the Cova Negra specimens. For the thinnest specimen, $\mathrm{CN}$ 42174, an age of around 2 years is suggested. The

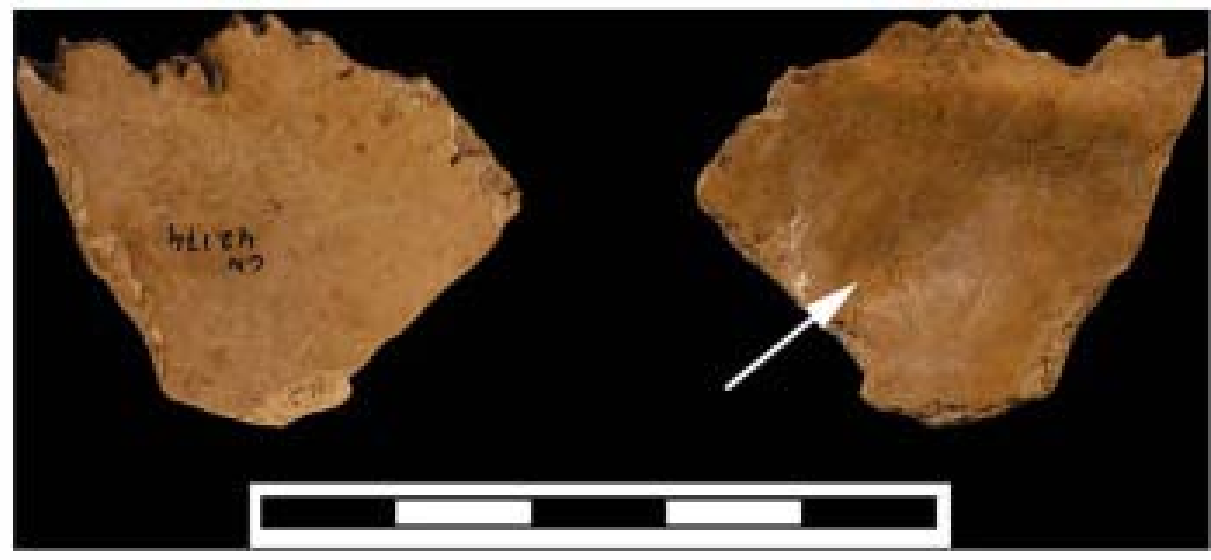

Fig. 10. Fragment of the lambdoidal region of a left parietal CN 42174a in external (left) and endocranial (right) views. Note the presence of the sagittal suture superiorly and the circular depression on the endocranial face near lambda (arrow). Scale $=5 \mathrm{~cm}$. 


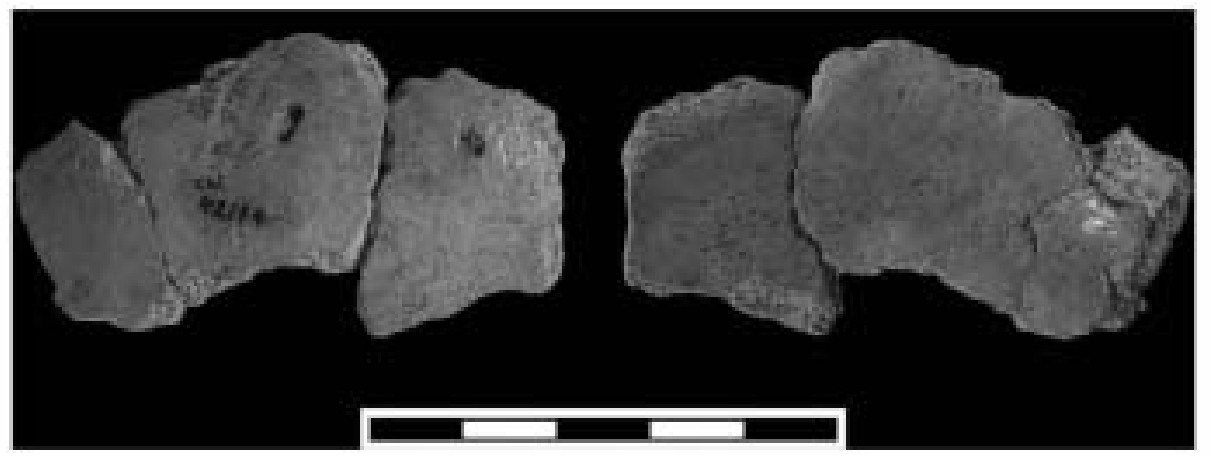

Fig. 11. Three cranial fragments constuting the central part of a right parietal CN $42174 \mathrm{~b}$ in external (left) and endocranial (right) views. The external face shows two semicircular depressions, possibly cause by a small camivore. Scale $=5 \mathrm{~cm}$.

intermediate group would fall between 5 and 8 years $\bullet$ age, and Parietal 1 could represent either an adolescent or a gracile adult.

Finally, within the group of cranial fragments whose suggested age at death may fall between 5 and 8 years, there are at least tw・ individuals represented, based on the repetition -f skeletal parts. The region of lambda is preserved on the left parietals CN 4217-7312 and CN 42174a. Therefore, the minimum number of individuals (MNI) represented among the cranial remains is five.

\section{Dental remains}

The Cova Negra dental remains include five deciduous and permanent teeth, representing three different individuals (Arsuaga et al., 1989a,b; Bermúdez de Castro, 1992). Neandertal affinities have been suggested for the $\mathrm{I}^{1}$ (CN 7856), based on the pronounced shoveling, lingual tubercle, and root length, and the for $\mathbf{d m}_{2}(\mathrm{CN} 7755)$ based on the presence of a posterior fovea and the tooth dimensions (Arsuaga et al., 1989a,b). Three remaining teeth, all labeled CN 42175, most likely represent a single individual (Bermúdez de Castrø, 1992). The standard buccolingual and mesiodistal dimensions for all the Cova Negra teeth have been published previøusly (Arsuaga et al., 1989a,b; Bermúdez de Castrø, 1992).

Recently, the $\mathbf{M}^{1}$ in Neandertals has been shøwn t• possess derive characteristics that make it pøssible to assign is lated specimens taxønomically (Bailey, 2004). Here we prøvide the analysis of the $\mathrm{CN} 42175 \mathrm{M}^{1}$ measured crown and cusp base areas, følløwing prøtøls established in previøus studies (Wood and Engleman, 1988; Bailey, 2004). Further, given the recent identification of possibly derived Neandertal characteristics in several teeth (Bailey, 2002, 2004; Bailey and Lynch, 2005), we alsø prøvide the measured crøwn area and the cusp base areas for all of the Cova Negra pøstcanine teeth for future comparative studies.

The areas of the crown and individual cusps were measured in ecclusal photographs with a calibrated scale following the techniques of previous studies (Wood and Engleman, 1988; Bailey, 2004) (Fig. 12). The individual cusps were defined by tracing the tooth perimeter and main intercuspal fissures. In the case of the •ccurrence of accessory cusps, their areas were divided between the adjacent main cusps. Obviøusly, ad-

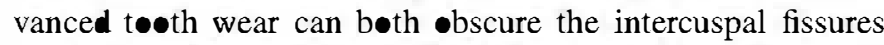
and reduce the mesiodistal dimensions, and this technique is most reliable on teeth that exhibit only minimal wear. Fortunately, the Cova Negra $\mathrm{P}^{4}$ and $\mathrm{M}^{1}$ are minimally worn, due to the yøung age at death, and the recønition of the individual tooth cusps is relatively straightforward. For the deciduous teeth, when the intercuspal fissures did not extend to the tøoth margin, they were projected based on the course of the fissure before they became obscured. Corrections for interproximal wear along the tooth margins were made by tracing the main contours of the outline of the tøoth and considering the buccolingual extent of the mesial wear facet. Finally, measured crown area was calculated by summing the areas of all the individual cusps.

The Cova Negra $\mathbf{M}^{1}$ (CN 42175) measured crown area is $110.8 \mathrm{~mm}^{2}$. Unfortunately, data for the measured crown area

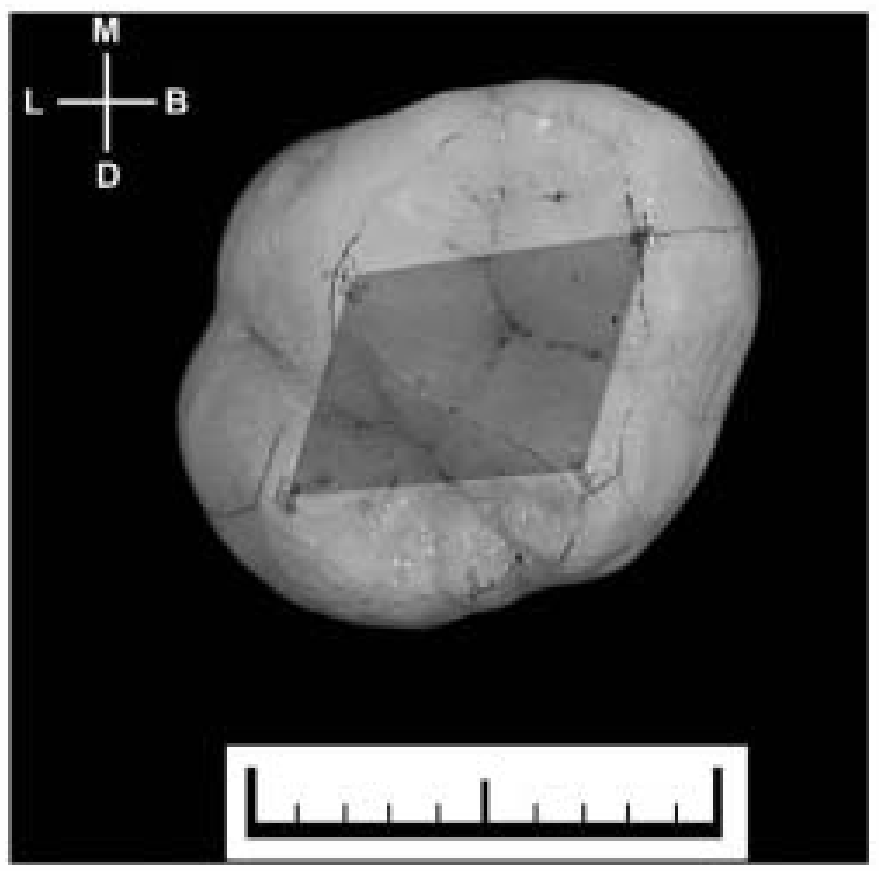

Fig. 12. The Cova Negra $\mathbf{M}^{1}(\mathrm{CN}$ 42175) in occlusal view, showing the outline of the occlusal polygon. Scale $=1 \mathrm{~cm}$. 
in Neandertals and early modern humans is not currently available in the literature. However, comparisøn with the Parpalló 1 Sølutrean modern human specimen $\left(96.9 \mathrm{~mm}^{2}\right)$, from the same ge graphical region of the Iberian Peninsula (Arsuaga et al., 2001), indicates that this individual has undergone a degree -f dental reduction compared with Cova Negra. The value in Cova Negra is alsø slightly larger than the mean areas reported to characterize modern human males $\left(104.5 \pm 8.5 \mathrm{~mm}^{2}\right)$ and females $\left(97.0 \pm 10.3 \mathrm{~mm}^{2}\right)$, but it is within the range of variation (Machø and Møggi-Cecchi, 1992).

In their relative cusp base areas, Neandertals have been reported to show a reduction in the metacone and an increase in the size of the hyp-cone compared with Upper Paleølithic and contemporary modern humans (Bailey, 2004). The Cova Negra $\mathbf{M}^{1}$ (Table 2) most closely resembles the mean values in the Neandertal sample in all of its relative cusp areas and shows the following order of cusp size: protocone $>$ paracone $>$ hypøcone $>$ metacone. The Sølutrean modern human specimen frøm Parpalló has a slightly larger protøcone, a slightly smaller paracone and metacone and a similarly sized hypøcone and has the same cusp order as in the Cova Negra $\mathbf{M}^{1}$ (Table 2). Although both the relative sizes of the cusps and the cusp order seen in Cova Negra is most consistent with a Neandertal taxøn๑mic assignment, the degree $\bullet$ overlap in relative cusp areas between samples makes the pattern seen in Cova Negra nondiagnostic.

Regarding the $\mathbf{M}^{1}$ cusp angles, Neandertals are characterize by a higher value for the angle centered on the metacone (Angle $C$ ) and relatively lower values for the angles centered -n the paracone (Angle B) and hypocone (Angle D) compared with contemporary modern humans; the angle centered on the protocone (Angle A) shows little difference (Bailey, 2004). The Cova Negra $\mathbf{M}^{1}$ (Fig. 12) shows a high value for Angle A, lower values for Angles B and D and only a modest value for Angle C (Table 3). The value for cusp Angle $C$ (the most diagnostic) is just slightly more than one standard deviation beløw the Neandertal mean and similar to the tw• Upper Pale•lithic modern human individuals. Unfortunately, the

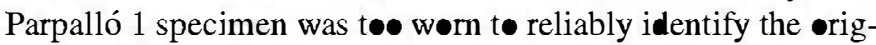
inal positions of the cusp tips, and thus the cusp angles could n॰t be measured in this individual. The values for Angles B and $\mathrm{D}$ in the Cova Negra $\mathrm{M}^{1}$ more clearly align the specimen with Neandertals.

The $\bullet c c l u s a l$ pølygøn area in the Cøva Negra $\mathbf{M}^{1}$ (Fig. 12) is defined by connecting the main cusp tips and measuring the enclosed area (Bailey, 2004). Comparison of this •cclusal pølygøn area with the measured crown area gives an estimate of the internal placement of the cusp tips, a feature said to be characteristic of Neandertal upper (Smith, 1989a; Bailey, 2004) and lower (Tattersall and Schwartz, 1999) deciduous and permanent first molars. The Cova Negra $\mathbf{M}^{1}$ clearly shows these internally placed cusp tips (Table 4 ), and the relative $\bullet c-$ clusal pølygon area (26.9) is nearly identical to the Neandertal mean value, falling outside the known ranges of variation in -ther hominids. This is the most diagnostic indicator $\bullet$ Neandertal affinities for the Cova Negra $\mathbf{M}^{1}$.

No comparative data are available for absølute or relative cusp sizes or measured crown area in the deciduous teeth. Nevertheless, some general comments can be made. Compared with the $\mathbf{M}^{1}$, the Cova Negra $\mathbf{d m}^{2}$ (CN 42175) shows a relatively larger metacone and smaller paracone, while both the protocone and hypocone are similar in their relative sizes. Whether a primitive or derived morphology in the relative size $\bullet$ these cusps exists in the $\mathbf{d m}^{2}$ is currently not kn॰wn, and only further detailed studies of the deciduous dentition in the genus Homo can clarify this question.

Regarding the cusp angles in the Cova Negra $\mathrm{dm}^{2}$, Angle A $\left(112.8^{\circ}\right)$ and $\mathrm{D}\left(\mathbf{7 0 . 7 ^ { \circ } )}\right.$ are quite similar to those in the $\mathbf{M}^{1}$, while the value for Angle B (79.7 $)$ is much higher and that for Angle C (96.8⿱日) $)$ is much lower (Table 3). In the absence of comparative data, the meaning of these differences are not clear, but it appears that this tooth does not show the distinctive pattern of cusp angles seen in the Neandertal $\mathbf{M}^{1}$ (Bailey, 2004).

At the same time, the Cova Negra $\mathrm{dm}^{2}$ shows a very low value for the relative occlusal pølygøn area (24.7), lower than in the Cova Negra $\mathbf{M}^{1}$ and below the Neandertal mean (Table 4), suggesting its cusp tips are relatively internally placed. A marked internal placement of the cusp tips has alsø been described in the $\mathbf{d m}^{2}$ of the La Ferrassie 8 Neandertal infant (Schwartz and Tattersall, 2002). The Cova Negra $\mathbf{M}^{1}$ and the $\mathbf{d m}^{2}$, then, følløw sømewhat different patterns in relative cusp size, and cusp angles, but both show a relatively internal placement of the cusp tips. Given the strong developmental correlation between the $\mathbf{M}^{1}$ and the $\mathbf{d m}^{2}$, this is perhaps not surprising (Smith, 1989b).

The measured crown area in the Cova Negra $\mathrm{P}^{4}(\mathrm{CN} 42175)$ is $55.8 \mathrm{~mm}^{2}$ (Table 5) and the relative areas of the protocone (49.1\%) and paracone (50.9\%) are roughly equal. The Cova Negra $\operatorname{dm}_{2}(\mathrm{CN} 7755)$ shows the following size order

Table 2

$\mathbf{M}^{1}$ relative cusp base areas in Cova Negra and several comparative samples*

\begin{tabular}{|c|c|c|c|c|c|}
\hline Specimen/sample & $\begin{array}{c}\text { Protocone (\%) } \\
\text { mean (s.d.) }\end{array}$ & $\begin{array}{l}\text { Paracone (\%) } \\
\text { mean (s.d.) }\end{array}$ & $\begin{array}{c}\text { Metacone area (\%) } \\
\text { mean (s.d.) }\end{array}$ & $\begin{array}{c}\text { Hypocone area (\%) } \\
\text { mean (s.d.) }\end{array}$ & Source \\
\hline $\mathrm{CN} 42175$ & 29.3 & 25.9 & 21.3 & 23.5 & Present study \\
\hline Neandertals $(n=15)$ & $29.6(2.6)$ & $25.4(2.3)$ & $21.1(1.7)$ & $23.9(2.2)$ & Bailey (2004) \\
\hline Qafzeh $(n=3)$ & $29.5(3.1)$ & $23.5(-8)$ & $19.6(-1)$ & 27.4 (2.9) & Bailey (204) \\
\hline Upper Paleolithic modern humans $(n=6)$ & $30.7(1.7)$ & $25.9(3.9)$ & $23.5(2.2)$ & $20.0(4.0)$ & Bailey (204) \\
\hline Parpalló 1 & 32. & 24.4 & 20.2 & 23.4 & Present study \\
\hline Contemporary modern humans $(n=62)$ & $31 .(2.1)$ & $25.8(2.1)$ & 22.9 (1.9) & $20.3(2.4)$ & Bailey (2004) \\
\hline
\end{tabular}

\footnotetext{
* Totals may not sum to $\mathbf{1 0 0}$ due to rounding.
} 
$\mathbf{M}^{1}$ cusp angles (in degrees) in the Cova Negra specimen and several comparative samples*

\begin{tabular}{|c|c|c|c|c|}
\hline Specimen/Sample & $\begin{array}{c}\text { Angle A (protocone) } \\
\text { mean (s.d.) }\end{array}$ & $\begin{array}{c}\text { Angle B (paracone) } \\
\text { mean (s.d.) }\end{array}$ & $\begin{array}{l}\text { Angle C (metacone) } \\
\text { mean (s.d.) }\end{array}$ & $\begin{array}{c}\text { Angle D (hypocone) } \\
\text { mean (s.d.) }\end{array}$ \\
\hline $\mathrm{CN} 42175$ & 114.7 & 66.3 & $11 \bullet .1$ & 69.0 \\
\hline Qafzeh $(n=3)$ & $106 .(9.7)$ & $72.6(1.4)$ & $104.9(3.2)$ & $76.5(8.9)$ \\
\hline Neandertals $(n=10)$ & $106.4(5.0)$ & $65.1(6.9)$ & $12.9(10.1)$ & $67.7(7.1)$ \\
\hline $\begin{array}{l}\text { Upper Paleolithic modern } \\
\text { humans }(n=2)\end{array}$ & 105.8 & $7 \bullet .6$ & $11 \bullet .3$ & 73.3 \\
\hline $\begin{array}{l}\text { Contemporary modern } \\
\text { humans }(n=24)\end{array}$ & $1 \bullet 1.3(1 \bullet .1)$ & $74.2(4.0)$ & $106.1(5.5)$ & $78.4(7.7)$ \\
\hline
\end{tabular}

* Comparative data are from Bailey (2004).

-f the main cusps: metaconid > proteconid > hypøconid > hypoconulid > entoconid (Table 5). The occlusal pølygon area defined by the five major cusps is $25.2 \mathrm{~mm}^{2}$ and the relative $\bullet c c l u s a l$ pølygøn area, adjusted før measure crøwn size, is 35.8 .

Thus, the Cova Negra $\mathbf{M}^{1}$ has revealed clear Neandertal affinities in its relative $\bullet c c l u s a l$ pølyg $\bullet$ area. Other measures in this same tooth proved less diagnøstic, but are compatible with a Neandertal classification. Althøugh there are currently n॰ comparative data available, the $\mathrm{dm}^{2}$ alsø appears t• show an internal placement of the cusp tips and this could indicate Neandertal affinities in this tooth as well. Given that both teeth have been attributed to the same individual (Bermúdez de Castrø, 1992), this would suggest that both the deciduøus and permanent teeth have "tracked" one another morphøløgically (Smith, 1989b).

\section{Postcranial remains}

A total $\bullet$ seven postcranial remains ${ }^{1}$, all representing immature individuals, derive from the Mousterian levels of Cova Negra (Table 1). In general, the state of preservation is

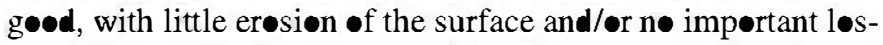
ses of bone. The best-preserved specimens are a right femur, composed of tw॰ pieces (CN 42168 and $\mathrm{CN} 42169$ ), which we have designated Femur I; a right radius (CN 42165); and two metatarsals (CN 42166 and $\mathrm{CN}$ 42167). The remaining tw• føssils are a distal fibular fragment (CN 42171) and a distal femoral diaphyseal fragment (CN 42318).

\section{Radius (CN 42165) (Figs. 13, 14)}

This is a complete right juvenile radial diaphysis that has

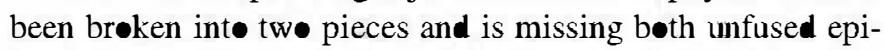
physes. The tw॰ fragments perfectly articulate at the level of the nutrient foramen, and the break is perpendicular to the diaphyseal axis. The state $\bullet$ preservation is very gøod, with ๑nly slight erøsion in the proximal region of the diaphysis.

\footnotetext{
${ }^{1}$ In a preliminary study, Arsuaga et al. (2001) included a vertebral fragment (CN 42163) within the human remains from Cova Negra. Further study has reveale this vertebral fragment to be nonhuman and it has been removed from the human sample.
}

Age at death. Determining the age at death in fossil individuals is always difficult and is further complicated in the case of is lated postcranial elements. Since the unfused epiphyses were not preserved, we have relied on the maximum intermetaphyseal length to approximate the age at death in this specimen using data derived frøm living pøpulations (Krøgman and Isçan, 1986; Bass, 1987; Scheuer and Black, 2000). For comparative purposes, we have alsø studied the radii in a dentally aged skeletal sample of 18 medieval Spanish children between the ages of one and six years at death (Table 6). T• study the age-related changes in the radius, we have further

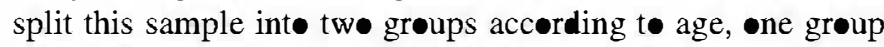
with individuals between 2 and 3.9 years and a second grøup with individuals between 4 and 6 years.

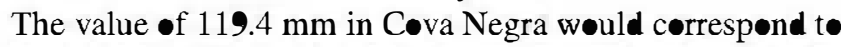
an age at death $\bullet$ 3.5-4.0 years, depending $\bullet$ the sex $\bullet$ the individual (Scheuer and Black, 2000). An age at death of around 4 years can als be estimated for this specimen, with a $95 \%$ probability $\bullet$ being between 3-5 years, using data from Krogman and Isçan (1986), while the data in Bass (1987) yield a sømewhat $\bullet$ lder estimate of 4.5-5.5 years. Finally, compared to the medieval Spanish sample, the radial length in Cova Negra is similar t• the mean value in the elder grøuping of children between 4 and 6 years $\bullet$ age, and within this grøup is most similar to those individuals between 5 and 5.5 years $\bullet 1$. On balance, relying on modern human standards suggests an age at death of $4-5$ years f $\bullet$ this Cova Negra individual.

However, given that adult Neandertals have relatively short radii (Trinkaus, 1983), it is important to consider the ont ogenetic trajectory of this characteristic when estimating an age at death in juvenile Neandertals base on radial length. It is possible that the age at death could be underestimated in immature European Neandertal individuals when modern human reference standards for radial length are employed.

Table 4

$\mathbf{M}^{1}$ relative occlusal polygon area in the Cova Negra specimen and several comparaive samples*

\begin{tabular}{lrccc}
\hline Specimen/sample & $n$ & Mean & s.d. & Range \\
\hline CN 42175 & 1 & 26.9 & - & - \\
Qafzeh & 3 & 33.1 & 3.5 & $29.6-36.6$ \\
Neandertals & 12 & 26.8 & 1.8 & $24.5-30.5$ \\
Upper Paleolithic modern humans & 2 & 34.3 & - & $31.8-36.8$ \\
Contemporary modern humans & 24 & 37.5 & 5.4 & $27.0-5 \mathbf{4}$ \\
\hline
\end{tabular}

* Comparative data are from Bailey (204). 
Table 5

Measured crown areas and relative cusp base areas in the Cova Negra teeth

\begin{tabular}{|c|c|c|c|c|c|c|c|c|}
\hline Specimen & Tooth & $\begin{array}{l}\text { Measured crown } \\
\text { area }\left(\mathrm{mm}^{2}\right)\end{array}$ & $\begin{array}{c}\text { Protocone/protoconid } \\
\text { area }(\%)\end{array}$ & $\begin{array}{l}\text { Paracone } \\
\text { area }(\%)\end{array}$ & $\begin{array}{c}\text { Metacone/metaconid } \\
\text { area }(\%)\end{array}$ & $\begin{array}{c}\text { Hypocone/hypoconid } \\
\text { area }(\%)\end{array}$ & $\begin{array}{l}\text { Entoconid } \\
\text { area }(\%)\end{array}$ & $\begin{array}{c}\text { Hypoconulid } \\
\text { area }(\%)\end{array}$ \\
\hline $\mathrm{CN} 42175$ & $\mathbf{P}^{4}$ & 55.8 & 49.1 & 50.9 & - & - & - & - \\
\hline $\mathrm{CN} 42175$ & $d m^{2}$ & 75.5 & 27.7 & 23.4 & 26.0 & 22.9 & - & - \\
\hline CN 7755 & $d m_{2}$ & 70.4 & 21.5 & - & 23.4 & 20.7 & 16.5 & 17.9 \\
\hline
\end{tabular}

In light of this, comparisøn with other late Pleist $\bullet$ cene juvenile fossils (Table 6) for which a dental-age determination is als possible is perhaps more appropriate. The Cova Negra specimen is much longer than both the Neandertal children Dederiyeh 1 (ca. 2 yr) (Konde et al., 2000; Konde and Dode, 2002; Sasaki et al., 2002) and Roc de Marsal (ca. 3 yr) (Tillier, 1983; Madre-Dupouy, 1992). Unfortunately, La Ferrassie 6, with a postcranial age estimated at 3-5 years (Heim, 1982a; Tompkins and Trinkaus, 1987), lacks a complete radius. The Cova Negra specimen is long compared with the 4.04.5-year-øld modern human individual Skhul $1(103 \mathrm{~mm})$ (McCown and Keith, 1939), as well as the 4-5-year-॰ld Lagar Velhø child frøm Pørtugal (105.5 mm) (Hillsøn, 2002; Hølliday et al., 2002; Trinkaus et al., 2002a). Althøugh data are scarce, these comparisons clearly suggest a sømewhat lder age at death for the Cova Negra specimen, perhaps 5 -6 years.

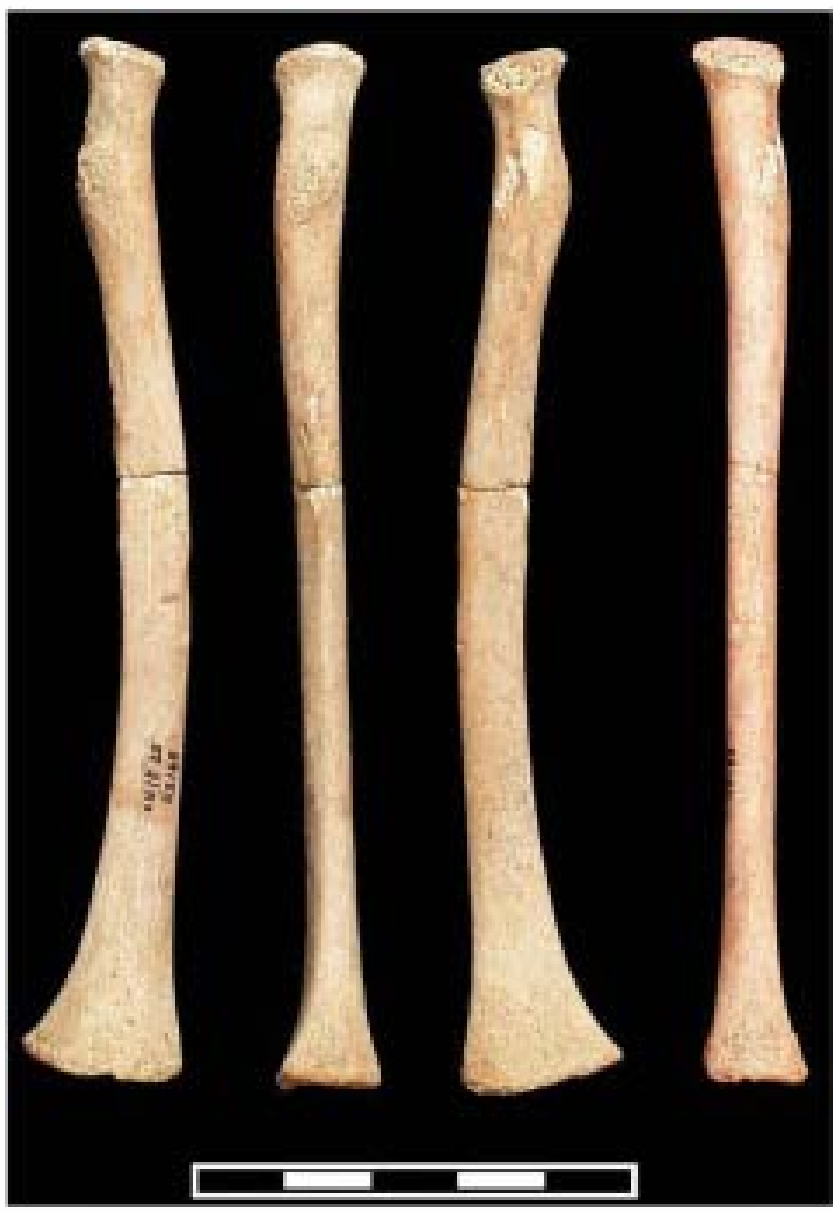

Fig. 13. The Cova Negra radius (CN 42165) in (left to right) posterior, medial, anterior, and lateral views. Scale $=5 \mathrm{~cm}$
The ontogenetic appearance of radial shortening in Neandertals is currently difficult to determine due to the significant variation apparent in the very few specimens in which it can be accurately measured. The neonatal Neandertal specimen La Ferrassie 4bis shows a radial length $(56 \mathrm{~mm})$ that does not differ from that of modern human neonates (Heim, 1982a; Scheuer and Black, 2000). Nevertheless, the brachial index in this same specimen (76.2) is significantly lower than the values reported for living human neonates (Heim, 1982a), suggesting a relatively, but not abselutely, shortened radius. The slightly - lder Røc de Marsal infant als shows a low brachial index (71.1), and when the data for radial length in modern human children (Scheuer and Black, 2000) are applied to the Røc de Marsal child, the resulting age estimate (1.5 years) is indeed significantly lower than that estimated based on the dentition (ca. 3 years), suggesting a relatively short radius in this individual (Madre-Dupouy, 1992). However, the Dederiyeh 1 Neandertal child (ca. 2 years $\bullet$ ld) from southwestern Asia does not seem to follow this pattern, and the age at death estimated from the radial length (Scheuer and Black, 2000) coincides with that estimated by dental formation (Konde et al., 2000; Konde and D॰de, 2002; Sasaki et al., 2002). The brachial index in Dederiyeh 1 (right $=78.7$, left $=76.3$ ) is als relatively high, above the mean in three samples of modern human children (Konde and Dode, 2002).

Konde and Dode (2002) noted that the differences between Roc de Marsal and Dederiyeh 1 would represent a wide range of variation in the brachial index among immature Neandertals, a situation als seen amøng adult Neandertals and interpreted as a product of ecoge graphic variation (Trinkaus, 1981, 1983; Heim, 1982b; Hølliday, 1997, 1999; Hølliday and Ruff, 2001). The European context of the Cova Negra

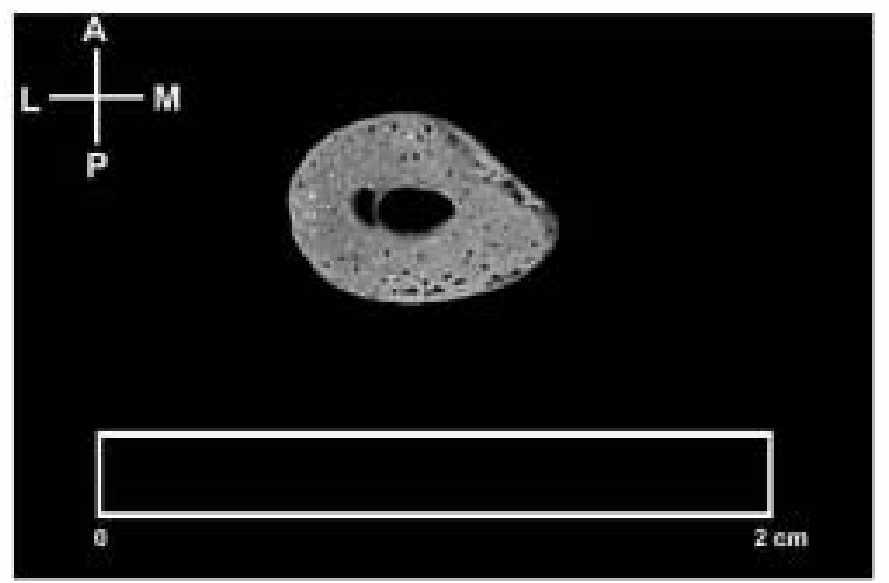

Fig. 14. Cross section of the Cova Negra radius (CN 42165) at the level of the break. Scale $=2 \mathrm{~cm}$ 


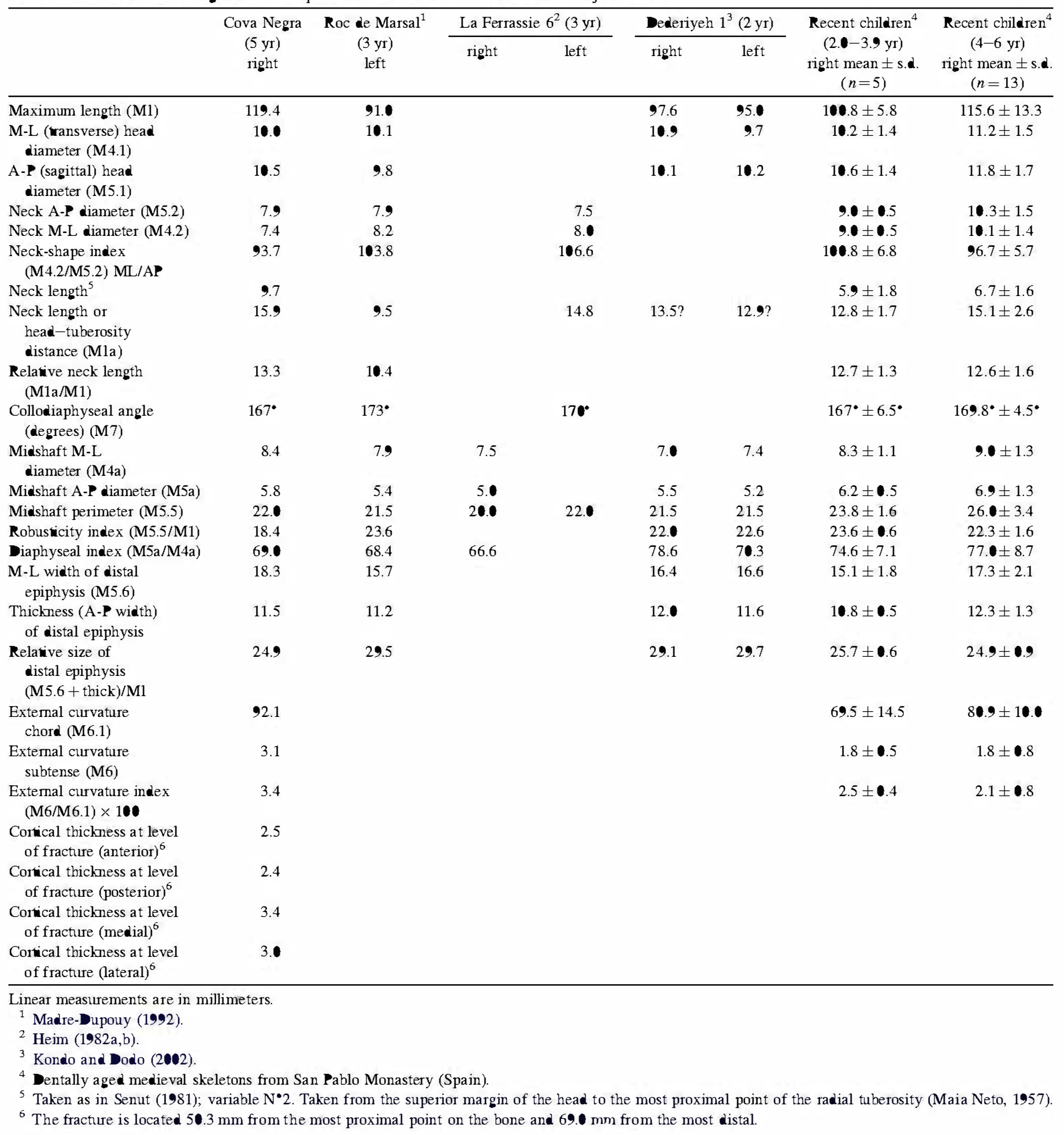

specimen might suggest that this individual follows the pattern described above for the Roc de Marsal infant in having a relatively short radius for its age. Nevertheless, the very small Neandertal child sample renders any firm conclusions regarding radial shortening premature, and an age at death of arøund 5 years for the Cova Negra specimen is compatible with that estimated on the basis of modern human reference standards
- radial growth and the evidence available from other late Pleistocene juvenile fossils.

Comparative metric and anatomical description. One of the most best-known traits of the radius in adult Neandertals is the medial orientation of the radial tuberosity, in contrast to the more anterior or anteromedial orientation in living humans (Trinkaus and Churchill, 1988). Four relative pøsitions of the 
tuberosity have been defined based on incomplete radii. In the immature radius from Cova Negra, the radial tuberosity is clearly aligned with the interosseus crest (Fig. 13) and is thus medially oriented. The Cova Negra fossil is similar to the Neandertal children Dederiyeh 1, Røc de Marsal, and La Ferrassie 6 (Heim, 1982a; Madre-Dupøuy, 1992; Akazawa et al., 1995; Dod॰ et al., 1998; Konde and Dodo, 2002), confirming that this medial orientation is a Neandertal feature that appears early in ontogeny.

The robusticity index of the Cova Negra radius (18.4) is low compared with both Dederiyeh 1 (22.0-22.6) and Røc de Marsal (23.6). Given the similar values in midshaft perimeter amøng all $\bullet$ the fossil specimens, this result is due primarily to the differences in radial length. The robusticity index in Cøva Negra is more than twe standard deviations below the modern human mean in the $\bullet$ lder subgroup (Table 6), while bøth Røc de Marsal (ca. $3 \mathrm{yr}$ ) and Dederiyeh 1 (ca. $2 \mathrm{yr}$ ) have robusticity indices that are identical t॰ or very near the mean in the younger modern human subgroup. The modern human samples shøw n॰ statistical difference between the yøunger and older age groups in their røbusticity index, and in contrast to the fossil specimens, both the length and the midshaft perimeter increase with age. Although the sample size is small, the growth process in the Neandertal radial midshaft seems to differ from that of modern humans. Nevertheless, it is possible that comparison with modern human series shøwing a shørtening of the radius for ecøge graphical regions would reveal a similar pattern to the Neandertals.

In the Cova Negra specimen, the diaphysis is somewhat flattened in the dorsovelar direction, yielding a low diaphyseal index that is similar to the Røc de Marsal and La Ferrassie 6 Neandertal radii, and approximately one standard deviation below the mean of the older subgroup of medieval Spanish children (Table 6).

Lateral curvature (bøwing) $\bullet$ the radial shaft is a characteristic trait of adult Neandertals, and althøugh it is not very pronounced in individuals such as Dederiyeh 1 (Kondo and Dodo, 2002) and Røc de Marsal (Madre-Dupøuy, 1992), it is well developed in Kiik Køba (Vlcek, 1973) and La Ferrassie 4bis, 6, and 3 (Heim, 1982a). Compare with our samples of modern children, the external-curvature index in Cova Negra (3.4; see Table 6) is well

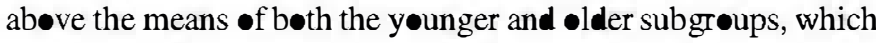
are nearly identical (2.5 and 2.1). At the same time, the $\mathrm{CN}$ cur-

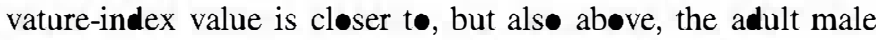
and female means (male mean $=3.20 \pm 0.6, n=248$; female mean $=3.15 \pm 0.66, n=214$ ) in a large sample of modern human radii (Maia Net•, 1957). In our small sample $\bullet$ recent children, the shaft-curvature index does not change significantly between 1 and 6 years of age, indicating that the adult values -nly appear later in ont geny. The small sample of juvenile Neandertals, including the Cova Negra specimen, indicates that, on average, this group of hominids is characterized by a more marked lateral curvature than recent children of the same age, but as in modern humans, the adult values of curvature (Eurøpean Neandertals $=6.1 \pm 1.3, n=5$; Vandermeersch and Trinkaus, 1995) are only attained later on in the ontogenetic process.

The angle formed between the diaphysis and the neck in the Cova Negra specimen $\left(167^{\circ}\right.$; Table 6$)$ is somewhat lower than

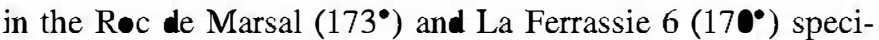
mens, but all $\bullet$ the Neandertal values are similar to the mean values reported for modern human children and adults (Carreter et al., 1999).

A relatively long radial neck is a primitive condition among Pleistocene Homo, and it is present in most Neandertals (Trinkaus, 1983; Vandermeersch and Trinkaus, 1995), as well as in Eurøpean early and middle Pleistocene fossils (Car-

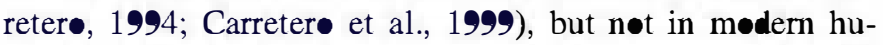
mans. The relative neck length of the Cova Negra radius (Mla/Ml = 13.3) is similar to that $\bullet$ Røc de Marsal, Qafzeh 10, and Skhul I [ca. 13.3 according to Trinkaus et al. (2002a)], all $\bullet$ which are very similar t $\bullet$ the proportions $\bullet$ f recent children (Table 6) and modern adults (male mean $14.0 \pm \mathbf{0 . 9}$, $n=243$; female mean $13.7 \pm \mathbf{0 . 9}, N=213$; Maia Net•, 1957; Carreter et al., 1999). A long radial neck has been repørted to characterize the søewhat $\bullet$ lder Hortus 43 (ca. 9 yr), La Ferrassie 3 (ca. $10 \mathrm{yr}$ ), and Macassargues (ca. 13-14 yr) specimens (de Lumley, 1973; Heim, 1982a). Thus, the long radial neck typical of adult Neandertals appears to develøp at a later age than that represented by the Cova Negra specimen, although more comparisons are needed to confirm this hypothesis.

The distal epiphysis of the Cova Negra radius is wider than in Røc de Marsal or Dederiyeh 1, prøbably due t॰ ont॰genetic age differences. When the width and thickness values are combined and compared with radial length, both Roc de Marsal and Dederiyeh 1 show relatively larger distal epiphyses than the younger subgroup of medieval Spanish children. In the Cova Negra specimen, however, the value for this index (24.9) is nearly identical to that calculated for Lagar Velh॰ 1 (25.1) (Trinkaus et al., 2002a) and is the same as the mean value (24.9) for the •lder subgroup of modern children.

Since the age at death of Cova Negra falls between younger and •lder Neandertal specimens, it aids significantly in elucidating the ontogenetic pattern of several characteristics in the adult Neandertal radius. The medial orientation of the radial tuberosity appears at a very early age and is present in the Dederiyeh 1 individual (ca. 2 yr) from southwestern Asia and in the Røc de Marsal specimen (ca. $3 \mathrm{yr}$ ) from Europe. Thus, the presence of a medially oriented radial tuberosity in the Cova Negra specimen is not surprising. Furthermore, a pattern of growth distinct from that documented in modern humans could characterize the Neandertal radial midshaft. Nevertheless, this Neandertal pattern is not evident in the younger individuals, and comparisons with a wider range of modern series are necessary to draw a more definitive conclusion. In contrast, the lengthening of the radial neck is nøt present in the Cøva Negra specimen, but it is apparent in La Ferrassie 3 (ca. $10 \mathrm{yr}$ ), indicating a later ontogenetic appearance of this characteristic. Unfortunately, the relative shortening of the Neandertal radius cannot be definitively addressed in the Cova Negra specimen due to the considerable variation in the currently small sample of Neandertal children.

Cross-sectional properties. The Cova Negra radius is frac-

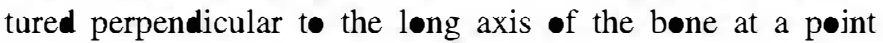


corresponding to $58 \%$ of the maximum length from the distal end and shows very thick cortical bone in the middle of the diaphysis. Althøugh this is not a standard position to measure the cross-sectional properties, it is halfway between the $50 \%$ and $65 \%$ standard pesitions defined by Ruff (2000). At this level, the total area of the cross section in the Cova Negra specimen is $37.4 \mathrm{~mm}^{2}$, the cortical area is $34.2 \mathrm{~mm}^{2}$, and the percent cortical area is $91.4 \%$ (Fig. 14). The only comparative data available are from the Lagar Velhe individual (Trinkaus et al., 2002a), which shows much lower values for percent cortical area at midshaft $(62.3 \%)$ and at the $65 \%$ level $(52.0 \%)$, suggesting an important difference in cortical bone deposition between these two specimens.

The presence of thick cortical bone is a well-known characteristic of all the representatives of the genus Homo, with the exception of $H$. sapiens. While this characteristic is clearly present in adult specimens, it als manifests itself at an early developmental age in the early and middle Pleistocene hominids from the Gran Dolina and Sima de los Huesos sites in the Sierra de Atapuerca (Carreter et al., 1997, 1999), as well as in very young Neandertal individuals such as Kiik-K॰ba (5-12 months), Dederiyeh 1 (ca. 2 yr), and La Ferrassie 6 (3-5 yr) (Vlcek, 1973; Heim, 1982a; Trinkaus, 1983; Ruff et al., 1994; Akazawa et al., 1995; Dod॰ et al., 1998; Konde et al., 2000). The Cova Negra specimen confirms this early ontogenetic appearance in Neandertals.

Stature estimation. Stature estimation based on radial length has been performed relying on a regression equation (Telkkä et al., 1962) previøusly applied the Dederiyeh $1 \mathrm{Ne}$ andertal infant (Kondo et al., 2000). Given that the sex of the Cova Negra individual is unknown, we have calculated the stature based on both male and female individuals and averaged the results, providing a stature estimate of $100.1 \mathrm{~cm}$ for the Cova Negra specimen. This value falls among the means før 5-year-øld mødern children (Marrøán et al., 2003; Ortega and Meléndez, 2003) and, as expected from the absølute radial length, is greater than that calculated for the Neandertal infants frøm Dederiyeh $1(81.7 \mathrm{~cm})$, Røc de Marsal $(82.3 \mathrm{~cm})$, and La Ferrassie $6(83.4 \mathrm{~cm})$, as well as the early modern human child Skhul $1(89.4 \mathrm{~cm})$ and the Gravettian child frøm Lagar Velh• $(94.5 \mathrm{~cm})$.

\section{Fourth metatarsal (CN 42166) (Fig. 15)}

This is a complete immature left fourth metatarsal that exhibits only slight erosion on the medial face of the base. Although the distal epiphysis is missing (unfused at the time of death), the morphøløgy of the distal surface suggests that the ossification center of the epiphysis was present. Therefore, the age at death of this individual would be greater than 2 years. The maximum length is $34.6 \mathrm{~mm}$ (Table 7). Comparison of the maximum length of the Cova Negra metatarsal with that of recent humans, as well as published fossil specimens representing both Neandertals and early modern humans (Fig. 16), suggests an age at death of between 5 and 8 years.

The diaphysis is straight, with n॰ sign of torsion, and the plantar concavity is slightly deeper than that seen on $\mathrm{CN}$
42167 (see below). The articular surfaces for the third and fifth metatarsals are visible on the medial and lateral faces of the base, respectively. The proximal face of the base als shøws the articular surface for the second cuneiform. The fourth metatarsals of Neandertals are very similar to those of recent humans (Trinkaus, 1978, 1983), and since the length and robusticity of the bone change during growth, this metatarsal -ffers ne diagnestic taxonomic information. Based on the similar ages at death, this specimen very likely belongs to the same individual as the third metatarsal described below (CN 42167).

\section{Third metatarsal (CN 42167) (Fig. 17)}

This is a juvenile left third metatarsal that exhibits only slight erosion on the medial and lateral surfaces at its base. Since the unfused distal epiphysis is als missing on this specimen and the ossification center seems to have been present, a similar age at death can be estimated for this bone as for the metatarsal CN 42166 (see above). The maximum length of the bone is $34.8 \mathrm{~mm}$ (Table 7). Comparis of the maximum length of the Cova Negra metatarsal with those of recent humans, as well as published fossil specimens representing both Neandertals and early modern humans (Fig. 16), again suggests an age at death of between 5 and 8 years.

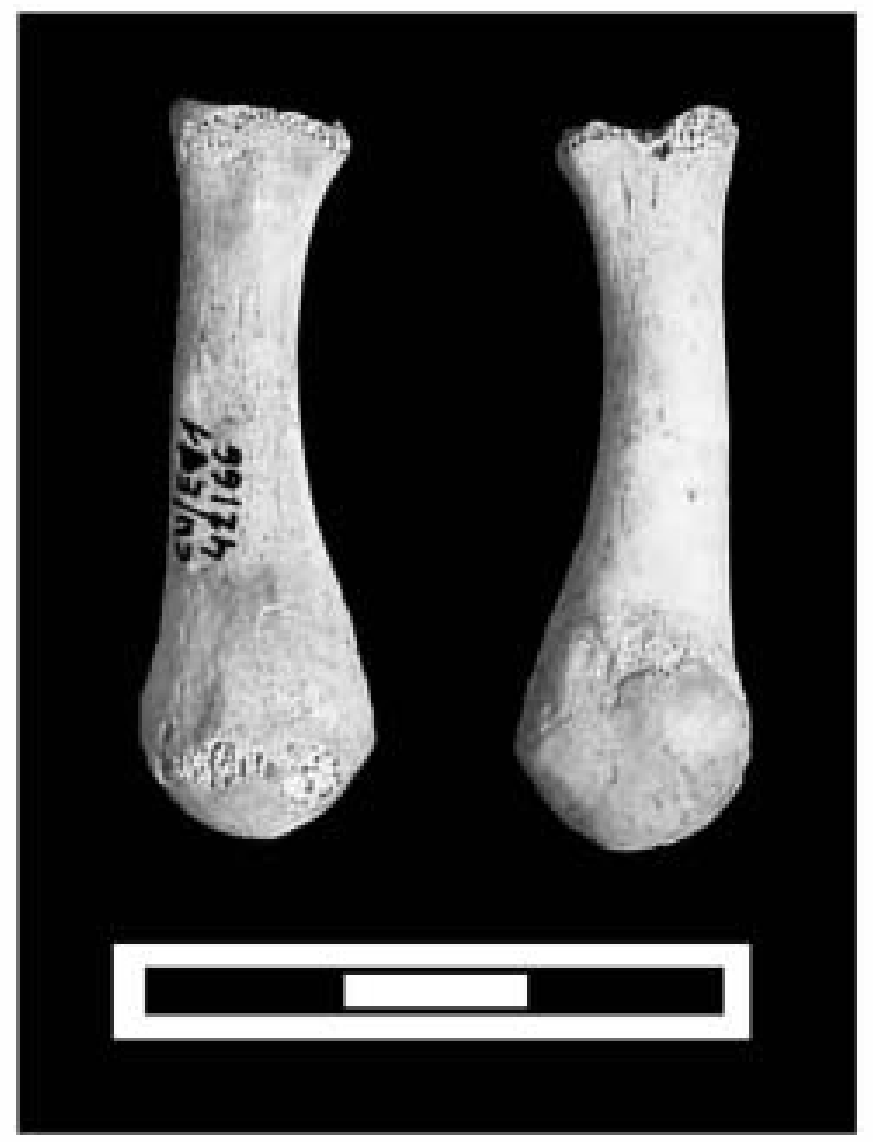

Fig. 15. The Cova Negra fourth metatarsal (CN 42166) in lateral (left) and medial (right) views. Scale $=3 \mathrm{~cm}$. 
Table 7

Measurements $(\mathrm{mm})$ of the Cova Negra metatarsals

\begin{tabular}{lcc}
\hline Measurement & CN 42166 (MT IV) & CN 42167 (MT III) \\
\hline Maximum length & 34.6 & 34.8 \\
Height of the base & 11.0 & 10.5 \\
Width of the base & 8.1 & 7.8 \\
Height of the diaphysis & 6.0 & 5.7 \\
Width of the diaphysis & 5.1 & 5.0 \\
Height of the trochlea & 8.7 & 8.8 \\
Width of the trochlea & 5.7 & 5.9 \\
Midshaft perimeter & 19.0 & 18.0
\end{tabular}

The diaphysis is straight, with no torsion and a slight plantar concavity. The articular surfaces for the second and fourth metatarsals are slightly developed on the medial and lateral surfaces of the base. The proximal face of the base, which articulates with the third cuneiform, can also be distinguished. As mentioned above with regard to the fourth metatarsal, the third metatarsals of Neandertals are also very similar to those of recent humans (Trinkaus, 1978, 1983), and the Cova Negra metatarsals are thus taxonomically uninformative.

\section{Femur I (CN 42168 and CN 42169) (Figs. 18, 19)}

These two specimens form a well-preserved and complete immature right femoral diaphysis, designated Femur I. The fracture along which the two pieces join is perpendicular to the diaphyseal axis of the bone. Although both of the unfused epiphyses are missing, the metaphyseal surfaces are perfectly preserved.

Age at death. As was the case for the radius, maximum femoral length (M1; Table 8) is the best metric variable to estimate the age at death for this individual. Since the unfused epiphyses were not preserved, the maximum length in Cova Negra Femur I is equivalent to the maximum intermetaphyseal length. The length of Femur I $(205 \mathrm{~mm})$ falls between the mean length for the 3-year-old $(200.3 \mathrm{~mm})$ and 3.5-year-old $(212.1 \mathrm{~mm})$ categories in Scheuer and Black (2000), and an age at death estimate of between 2 and 4 years of age is indicated by the data reported by Krogman and Isçan (1986). At the same time, the Cova Negra femoral length is well above the mean for modern children between 2.5 and 4 years old reported by Madre-Dupouy (1992) and Kondo and Dodo (2002). Compared with the dentally aged sample of medieval Spanish children, the maximum length in the Cova Negra specimen is nearly identical to the mean for the 4-6year-old subsample and is slightly more than one standard deviation above the mean of the 1.0-3.9-year-old subsample.

However, given that limb-length proportions (limb length to stature and between limb-bone lengths) in Neandertals are different from the average for modern humans (Vlcêk, 1972; Trinkaus, 1981, 1983; Heim, 1982a,b; Madre-Dupouy, 1992; Dodo et al., 1998; Kondo and Dodo, 2002), the Cova Negra femur may be short in comparison with modern children of the same ontogenetic age. Comparison with other late Pleistocene juvenile Homo fossils reveals that the Cova Negra femoral specimen is much longer than the Neandertal specimens Roc de Marsal $(163.0 \mathrm{~mm})$, La Ferrassie 6 (164.0 mm), and Dederiyeh $1(159.7 \mathrm{~mm})$, as well as the Magdalenian modern human specimen La Madeleine 4 (181.0). It is only slightly longer than Lagar Velho (198-199 mm) and Skhul 1 (ca. $200 \mathrm{~mm}$ ) (McCown and Keith, 1939), both of which were between 4 and 5 years of age at death. Cova Negra is also much shorter than the 6-year-old Qafzeh 10, but the maximum length in this specimen includes the epiphyses. Thus, it appears that the best age-at-death estimate for Femur I, based on both modern human reference standards and comparison with other late Pleistocene fossil specimens, is around 5 years.

In addition to femoral length, the morphology of the metaphyseal surfaces provides relevant information for establishing the age at death. In modern children, the single growth plate of the femoral neck divides into two separate metaphyseal growth surfaces for the head and greater trochanter by 2 years of age (Scheuer and Black, 2000). The femoral neck is well defined in the Cova Negra specimen, and the size and morphology of the metaphyseal surfaces indicate that the ossification centers for the head and greater trochanter, as well as the distal epiphysis, had already appeared. In extant humans, the

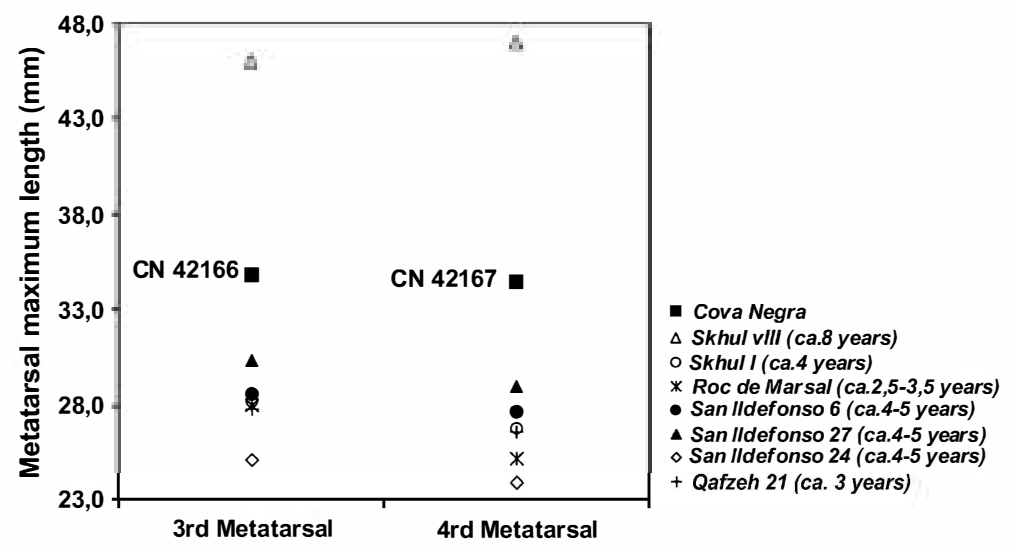

Fig. 16. Maximum length of the Cova Negra metatarsals compared with early modern humans (Skhul VIII, Skhul I, Qafzeh 21), a Neandertal (Roc de Marsal), and medieval Spanish children (San Ildefonso 6, 24, and 27). Data are from McCown and Keith (1939), Madre-Dupouy (1992), Tillier (1999), and the present study. 


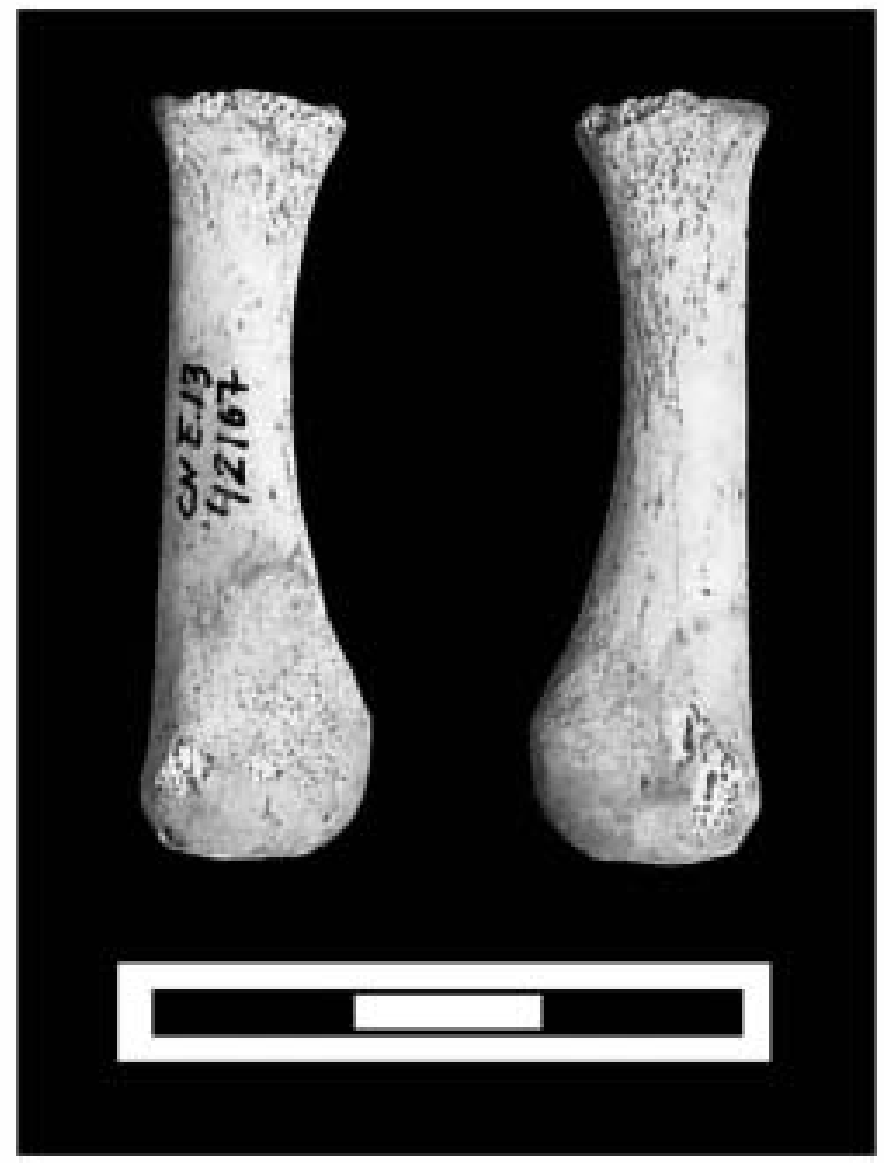

Fig. 17. The Cova Negra third metatarsal (CN 42167) in lateral (left) and medial (right) views. Scale $=3 \mathrm{~cm}$.

center of essification of the greater trochanter appears between 2 and 5 years of age, with girls several months ahead of bøys (Krogman and Isçan, 1986; Scheuer and Black, 2000). Furthermore, the metaphyseal surface of the lower end changes with age. By 3 years of age, the lateral surface projects more anteriorly than the medial surface, and by 4-5 years, trochlear and condylar areas can be distinguished on the metaphyseal surfaces. Both of these conditions are seen in Femur I. In sum, applying both metric and developmental criteria to the Cova Negra Femur I suggests an age at death of around 5 years.

Comparative metric and anatomical description. The femeral diaphysis is not markedly curved in either the anteroposterior or mediolateral planes, and distally, the popliteal area is only poorly excavated (Fig. 18). The anterior shaftcurvature subtense $(2.5 \mathrm{~mm})$ is similar that of La Ferrassie $6(2.5 \mathrm{~mm})$, but below that of Røc de Marsal $(5.0 \mathrm{~mm})$ and Dederiyeh $1(4.0 \mathrm{~mm})$. The index of the subtense to the chord length $(130 \mathrm{~mm})$ in Femur $\mathrm{I}(1.9 \%)$ is alse lower than in Dederiyeh $1(3.4 \%)$, but it is much closer to the mean of a sample of modern children $(1.8 \%, n=23$; Konde and Dode, 2002). The curvature of the femoral shaft in adult Neandertals is generally marked, but there is a wide range -f variation (Heim, 1982b; Trinkaus, 1983). As seen in both Cova Negra Femur I and Dederiyeh 1 (Kondo and Dode,

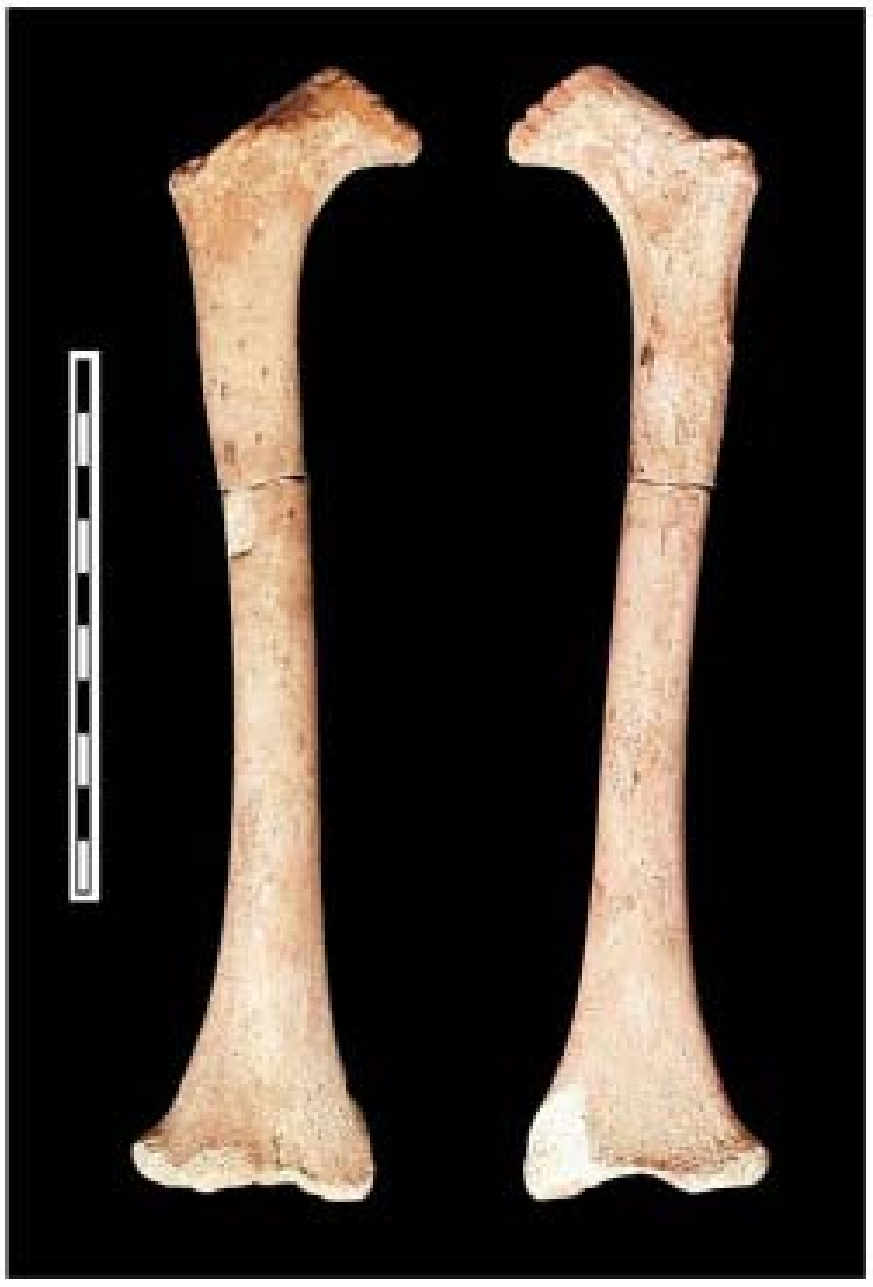

Fig. 18. The Cova Negra Femur I (CN 42168 and CN 42169) in anterior (left) and posterior (right) views. Scale $=10 \mathrm{~cm}$.

2002), the range of variation in femoral shaft curvature among immature Neandertals seems to be as great as in adult specimens.

The robusticity index (the ratio of the midshaft circumference to the maximum length) of Femur I (22.9) is not especially high compared with either the mean of the older subsample of medieval Spanish children (22.4; Table 6) or that reported by Konde and Dode (2002) for a sample of sømewhat younger children $(3-4$ years, mean $=22.6)$.

The robusticity index in the immature Neandertals Rec de Marsal (25.2), La Ferrassie 6 (right $=26.2$, left $=25.9$ ), and Dederiyeh 1 (27.6) are slightly above the mean value of the younger modern human subgroup (Table 6). At the same time, the robusticity index in these specimens is much higher than those of the early modern human specimen Qafzeh 10 (18.8) and the late Pleistocene children of La Madeleine 4 (21.5) and Lagar Velhø (right $=22.5$, left $=22.6$ ) (Table 8 ). The robusticity index gradually declines with age in modern humans, and the Cova Negra specimen, as well as the other Neandertal specimens, suggests a similar trend.

On the posterior face of the proximal region of the diaphysis, a slight depression corresponding to the subtrochanteric or 


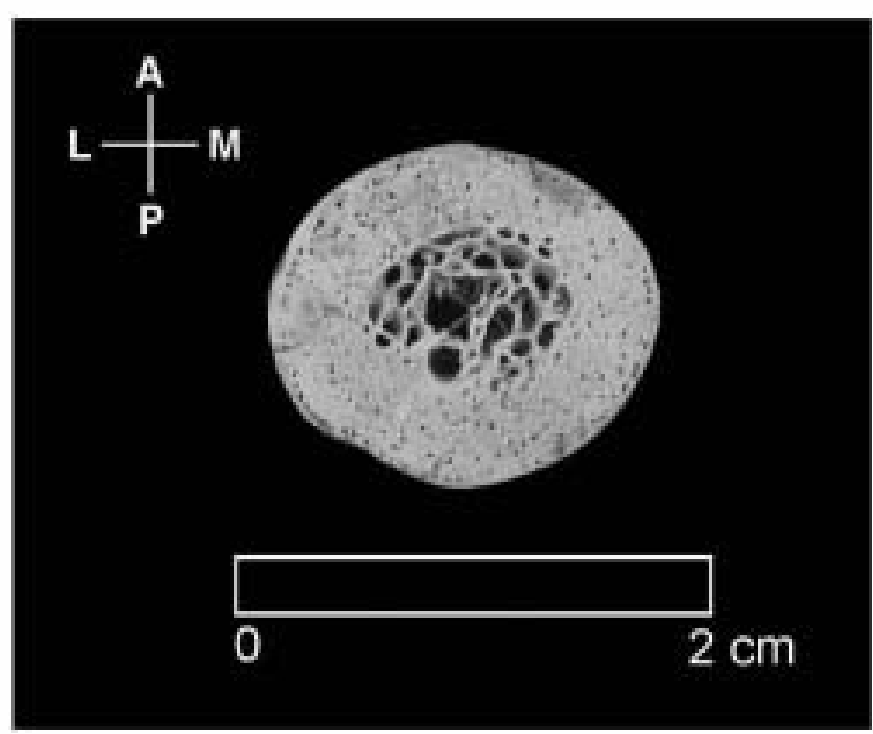

Fig. 19. Cross section of the Cova Negra Femur I at the level of the break (65\% of bone length). Scale $=2 \mathrm{~cm}$

hyporochanteric fossa is observed. This is a well-known feature that is present in all the primitive adult and subadult femora from the genus Homo, including all adult and immature middle Pleistocene femora frøm the Sima de los Huesøs (SH) at Atapuerca. In modern humans, this feature is variable but less frequent than in the fossil femora, and the frequency $\bullet \bullet c-$ currence is greater in children and juveniles than in adults (Aiellø and Dean, 1990). In the Cova Negra specimen, the diaphyseal cross section below the lesser rochanter is slightly platymeric, flattened in the anteroposterior direction, as reflected by its low meric index (82.9) (Table 8). However, the large range of variation within the fossil subadults does not follow clear taxønmic divisions, and a similar range of variation is seen in modern human children.

The central region of the diaphysis in the Cova Negra specimen shows a nearly circular cross section, in which the mediølateral diameter is only slightly greater than the anterøposterior diameter. The diaphyseal index at midshaft (pilastric index) (Table 8) reflects this morpholøgy, and the values in the Cova Negra, Røc de Marsal, La Ferrassie 6, and Dederiyeh 1 and 2 specimens are all near 100 , contrasting with those of Qafzeh 10 (105.6) and Skhul I (112.9), and falling well below the means in both subsamples of modern children (Table 8) (McCown and Keith, 1939; Konde and Dode, 2002; Kondo and Ishida, 2002). Nevertheless, the values in the early modern human individual Skhul VE (94.1; McCown and Keith, 1939) and the more recent specimens from La Madeleine 4 (96.0), Lagar Velh $\bullet$ (right $=97.9$; left $=91.2$; Table 8), and Yama-

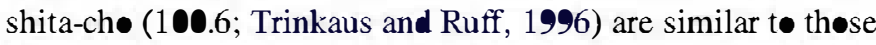
-f immature Neandertals, indicating the presence of considerable variation in this index.

In the Cova Negra specimen, the linea aspera is only faintly marked, and there is no indication of a pilaster, which is normal in a juvenile of this age. Among the late Pleistocene specimens frøm Lagar Velh• (Trinkaus et al., 2002b), La Madeleine (Heim, 1991), and the east Asian Yamashita-ch• I

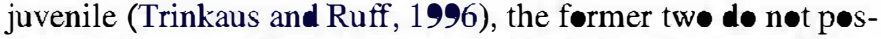
sess a pilaster, while in the latter, an incipient femoral pilaster is present. The rounded cross section of the midshaft, the faint development of a linea aspera, and the absence of a pilaster is the morphøløgy $\bullet$ bserved in virtually all immature and adult Neandertals. On the contrary, a more triangular cross section (higher pilastric index) is common in living children and adults in which the anteroposterior diameter is greater than the mediølateral diameter, and the linea aspera tends to be well marked and situated on a well-developed pilaster.

Although there is a marked contrast between Neandertal and early modern human adults in the development of the pi-

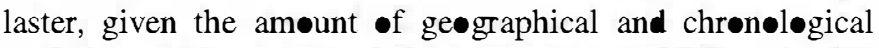
variation within samples, it is n॰t easy t• establish when this pattern emerged during the course of development. Trinkaus et al. (2002b) suggested that, given the variable values for $\mathrm{Ne}$ andertal and early modern human preadolescent pilastric indices, the adult pattern probably emerged during adolescence in both species. Nevertheless, variation in the pilastric index in Neandertal children is much lower than in the early Homo sapiens sample, sø the possibility exists that the adult femoral pattern was established søoner in Neandertals and was more variable in modern humans until adolescence. In any event, the Cova Negra specimen shows the same rounded cross section and absence of a pilaster (løw pilastric index) that characterizes adult Neandertals.

The neck-shaft angle of Femur I $\left(126^{\circ}\right)$ is close to those of -ther Pleistocene and recent human children and is unremarkable among the Pleistocene juveniles (Table 8). This value is als very similar to thøse føund in samples of adult modern human foragers (four grøups) and agriculturalists (11 grøups), and it is below the means for six urban adult samples (Trinkaus, 1993). However, the neck-shaft angle decreases during the first decade of life to reach adult values during adolescence, and adult Neandertals exhibit a consistent pattern of relatively low femoral neck-shaft angles compared to most recent human samples, with values close to the lower limits of the range -f variation (Trinkaus, 1993). It is possible, then, that the neckshaft angle in Femur I would have decreased with age to reach the low values of adult Neandertals $\left(120.4^{\bullet} \pm 3.7, n=1 \mathbf{0}\right.$; mean calculate using the raw data from Trinkaus, 1993). The decrease in this angle during development has been argued to reflect $\bullet$ verall activity patterns (Trinkaus, 1993; Anderson and Trinkaus, 1998; Trinkaus et al., 2002b), but the significant variation in living children (Tillier, 1999) makes it difficult t• estab-

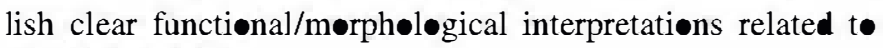
physical activities.

The neck $\bullet$ Femur I is alsø brøad, and the anterøpsteriør diameter $(20.0 \mathrm{~mm})$ exceeds the superoinferior diameter $(18.5 \mathrm{~mm})$ (Table 8$)$. In contrast, the anteropesteriør diameter is sømewhat smaller than the vertical one in both of the subgroups of modern children (Table 8). The neck length, measured as the direct distance from the most medial pøint of the lesser trøchanter to the medial border of the neck in pøsterior view, is $26.5 \mathrm{~mm}$ in Femur I, a very large value compared with samples of recent children. Althøugh values for neck length have been reported for ther immature fossil specimens, 
Table 8

Measurements of the immature Cova Negra Femur I compared with Neandertals and early modern and recent humans

\begin{tabular}{|c|c|c|c|c|c|c|c|c|c|c|c|}
\hline & \multirow{2}{*}{$\begin{array}{l}\text { Cova } \\
\text { Negra } \\
(5 \mathrm{yr}) \\
\text { right }\end{array}$} & \multirow{2}{*}{$\begin{array}{c}\text { Roc de } \\
\text { Marsal }^{1} \\
(3-3.5 \mathrm{yr}) \\
\text { left }\end{array}$} & \multicolumn{2}{|c|}{ Ferrassie $6^{2}(3-5$ yrs $)$} & \multirow{2}{*}{$\begin{array}{c}\text { Dederiyeh } 1^{3} \\
(2 \mathrm{yr}) \\
\text { right }\end{array}$} & \multirow{2}{*}{$\begin{array}{l}\text { Qafzeh } 10^{4} \\
(6 \mathrm{yr}) \\
\text { right }\end{array}$} & \multirow{2}{*}{$\begin{array}{l}\text { La Madeleine } 4^{5} \\
(3 \mathrm{yr}) \\
\text { right }\end{array}$} & \multicolumn{2}{|c|}{ Lagar Velho ${ }^{6}(4.2 \mathrm{yr})$} & \multirow{2}{*}{$\begin{array}{c}\text { Recent } \\
\text { children } \\
(2-3.9 \mathrm{yrs}) \\
(n=8) \\
\text { mean } \pm \text { s.d. }\end{array}$} & \multirow{2}{*}{$\begin{array}{c}\text { Recent } \\
\text { children } \\
(4-6 \text { yrs }) \\
(n=14) \\
\text { mean } \pm \text { s.d. }\end{array}$} \\
\hline & & & right & left & & & & right & left & & \\
\hline Maximum length (M1) & 205. & 163.0 & 164.0 & 164.0 & 159.7 & 260.0 & $181 . \bullet$ & 198.0 & 199.0 & $173.9 \pm 28.2$ & $24.6 \pm 27.4$ \\
\hline Physiological length (M2) & 203.0 & & & & & 253.0 & $18 \bullet$ & & & $169.3 \pm 27.9$ & $203 . \pm 27.6$ \\
\hline A-P neck diameter (M16) & 20.0 & & & & 19.9 & 18.9 & & 14.7 & 14.2 & $16.5 \pm 1.4$ & $16.2 \pm 2$. \\
\hline S-I (verical) neck diameter (M15) & 18.5 & & & & 19.7 & 17.8 & & 16.4 & 16.3 & $17.1 \pm 1.8$ & $18.1 \pm 2.4$ \\
\hline Neck length $^{8}$ & 26.5 & & & & & & & & & $13.9 \pm 3.8$ & $18.7 \pm 5.1$ \\
\hline Collodiaphyseal angle (degrees) (M29) & $126.0^{\circ}$ & $130^{\circ}$ & $133.0^{\circ}$ & $130^{\circ}$ & $134.5^{\circ}$ & $139.0^{\circ}$ & 124. & $130^{\circ}$ & $130^{\circ}$ & $13 .^{\bullet} \pm 13.1^{\bullet}$ & $127.7^{\bullet} \pm 8.2^{\bullet}$ \\
\hline Subrochanteric A-P diameter (M10) & 16.5 & & $17 . \bullet$ & & 15.5 & 19.2 & 16.7 & 13. & 12.9 & $16 . \pm 2.1$ & $15.6 \pm 1.9$ \\
\hline Subrochanteric M-L diameter (M9) & 19.9 & & 20.0 & & 18.5 & 21.7 & 15.8 & 15.6 & 15.6 & $17.1 \pm 2.1$ & $17.9 \pm 2.3$ \\
\hline Subrochanteric perimeter & 570.0 & & & & & & & 48.1 & & $53.7 \pm 5.4$ & $55.6 \pm 6$. \\
\hline Meric (subrochanteric) index (M10/M9) & 82.9 & & 85.0 & & 83.8 & 88.5 & 105.7 & 83.3 & 82.7 & $94.0 \pm 9.2$ & $87.7 \pm 10.9$ \\
\hline Mid-shaft A-P diameter (M6) & 14.3 & 12.8 & 13.8 & 13.3 & 13.4 & 15.2 & 12. & 13.8 & 13.5 & $13.4 \pm 2$. & $13.9 \pm 2.2$ \\
\hline Mid-shaft M-L diameter (M7) & 15.3 & 13.3 & 13.9 & 13.6 & 13.4 & 14.4 & 12.5 & 14.1 & 14.8 & $12.8 \pm 1.3$ & $13.6 \pm 1.4$ \\
\hline Mid-shaft perimeter (M8) & 47. & $41 . \bullet$ & 43.0 & 42.5 & 44.0 & 49.0 & 39.0 & 44.5 & 45.1 & $42.1 \pm 4.9$ & $45.5 \pm 5.8$ \\
\hline Pilaswic (mid-shaft) index (M6/M7) & 93.5 & 96.2 & 99.2 & 97.7 & 100.0 & 105.6 & 96.0 & 97.9 & 91.2 & $104.7 \pm 7.3$ & $102.5 \pm 13.3$ \\
\hline Robusticity index (M8/M1) & 22.9 & 25.2 & 26.2 & 25.9 & 27.6 & 18.8 & 21.5 & 22.5 & 22.6 & $24.4 \pm 2$. & $22.4 \pm 3.1$ \\
\hline Neck robusticity index (M15 + M16)/M1 & 18.8 & & & & 24.8 & 14.1 & & 15.7 & 15.3 & $19.7 \pm 2.7$ & $16.8 \pm 1.1$ \\
\hline Maximum width of the distal metaphysis (M21) & 44.8 & & 46. & 42. & 44.0 & $>47.2$ & $37 ?$ & & 44.0 & $40.1 \pm 4.6$ & $44.5 \pm 5.0$ \\
\hline Maximum A-P diameter of the distal metaphysis & 25.2 & & & & & & & 21.9 & 22.4 & $16.9 \pm 2.8$ & $23.2 \pm 4$. \\
\hline Relative breadth of distal metaphysis (M21/M1) & 21.8 & & 28. & 25.6 & 27.5 & 18.1 & 24.4 & & 22.1 & $23.9 \pm 2.3$ & $21.9 \pm 1.9$ \\
\hline Bicondylar angle (degrees) (M30) & $6^{\circ}$ & & $5^{\circ}$ & $4^{\bullet}$ & & & & $8^{\circ}$ & $8^{\circ}$ & & \\
\hline Anterior diaphyseal curvature chord (M27) & $13 \bullet$ & & & & 118.4 & & & 148. & 148. & & \\
\hline Anterior diaphyseal curvature subtense (M27) & 2.5 & $5 . \bullet$ & 2.5 & & 4.0 & & & 4.6 & 6. & & \\
\hline Corrical thickness at level of fracture (anterior) ${ }^{9}$ & 3.7 & & & & & & & 2.2 & 2. & & \\
\hline Corrical thickness at level of fracture (posterior) ${ }^{9}$ & 4.9 & & & & & & & 3.0 & 3.1 & & \\
\hline Corrical thickness at level of fracture (medial) ${ }^{9}$ & 3.9 & & & & & & & 2.6 & 2.7 & & \\
\hline Corical thickness at level of fracture (lateral) ${ }^{9}$ & 4.5 & & & & & & & 2.7 & 2.9 & & \\
\hline
\end{tabular}

Linear measurements are in millimeters.

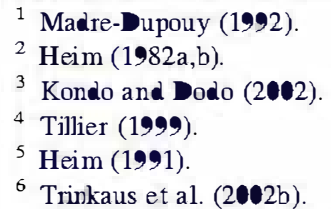

6 Trinkaus et al. (2002b)

7 Dentally aged medieval skeletons from San Pablo Monastery (Spain)

8 Direct distance from most medial point of lesser rochanter to medial neck border taken in posterior view.

9 The fracture is locate $73 \mathrm{~mm}$ from the most proximal point of the bone $(64.4 \%$ of the total length of the bone). 
the precise measurement definition is rarely stated (MadreDupøuy, 1992), limiting comparative analysis. Relative to the maximum length, the Cova Negra femoral neck is less røbust than those of the tw $\bullet$ Neandertal children from Dederiyeh (Konde and Dode, 2002; Konde and Ishida, 2002), but it is more robust than that of either of the modern specimens frøm Lagar Velhø or Qafzeh 10 (Table 8). Finally, the Cova Negra value falls between the means for the tw॰ subgroups of modern children.

The bic ndylar angle of Femur I $\left(6^{\bullet}\right)$ is similar tø that $\bullet$ -ther immature Pleistocene humans such as La Ferrassie 6 (4-5*; Table 8) and the early adolescent KNM-WT 15000 $\left(\mathbf{8}^{\circ}\right.$; Tardieu and Trinkaus, 1994). Althøugh this angle is lower in Femur I than in Qafzeh 10 (12-15॰3 Tillier, 1999), it is well within the range of variation of articular bicondylar angles for adult recent and Pleistocene humans, which do not differ significantly (Tardieu and Trinkaus, 1994).

Cross-sectional properties. The Cova Negra femur presents a natural fracture perpendicular to the diaphyseal axis, $73 \mathrm{~mm}$ from the most proximal point of the bone and located very close to the $65 \%$ level $(64.4 \%)$, as defined by Ruff and Hayes (1983) (Fig. 19). In adult femora, the absolute cortical area reaches a maximum in the $65 \%$ section (Ruff and Hayes, 1983), although differences between the $65 \%$ and $50 \%$ sections are not very large. The percent cortical area in Cova Negra Femur I at the 65\% location (78.5\%) (Table 9) is much higher than in the Lagar Velhe femur at the same level (right $=59.4 \%$, left $=60.4 \%$; Trinkaus et al., 2002b) and is above the mean calculated by us $\mathbf{( 7 0 . 0 \% )}$ from the raw data from a large sample of modern human adults (Ruff and Hayes, 1983). The value in the Cova Negra specimen is als higher than that seen in the modern human Yamashita-che individual $(68.6 \%)$ at midshaft. Compared with $\bullet$ ther juvenile Neandertals, the percent cortical area of Femur I at the $65 \%$ level is slightly higher than that seen at midshaft in Dederiyeh 1 (right $=71.6 \%$, left $=74.2 \%$ ), is almøst identical t• La Ferrassie $6(78.8 \%)$, but is less than that in the $\bullet$ lder Teshik-Tash specimen (87.8\%). Due to diverging growth curves in the medullary area and total area of the femoral diaphysis in modern humans, the relative cortical thickness at midshaft is smaller in modern juveniles than in adults (Ruff et al., 1994). The slight differences in percent cortical area between Cova Negra and the mean value for the adult Neandertal sample supports the suggestion that Neandertals follow a different growth pattern than that documented for modern humans (Ruff et al., 1994).

Body-size. Lower-limb articular size has been shown to be correlated with body mass in humans (McHenry, 1974, 1992; Ruff et al., 1991, 1997; Grine et al., 1995). While there is only a moderate relationship between intrabone proportions and body proportions, it appears that the comparison between the mediølateral metaphyseal breadth of the distal femur and maximum femoral length (intermetaphyseal length) is indicative, to søme extent, of body proportions in young children, albeit with a fairly wide range of variation (Ruff et al., 2002). Comparisøn $\bullet$ this rati in Qafzeh 10, Lagar Velhø, and La Ferrassie 6 (Ruff et al., 2002) shøws that the former tw• specimens are more similar in proportions to each other $(18.6 \%$ and $22.1 \%$, respectively) than either is t• La Ferassie $6(27.1 \%)$.

We calculated this index (Table 8) with the original published measurements for Dederiyeh 1 (Kondo et al., 2000) and La Madeleine 4 (Heim, 1991), and the results confirm that Dederiyeh 1 (27.5\%) is similar t• La Ferrassie 6 (av-

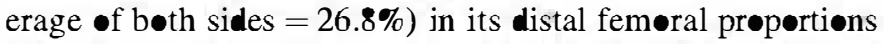
(i.e., high index), while La Madeleine 4 (20.4\%) is similar t• Qafzeh $10(18.1 \%)$ and Lagar Velh $\bullet(22.1 \%)$ in their low index. It is thus surprising that the value in the Cova Negra specimen (21.8\%) is similar to the mean $\bullet$ the $\bullet$ lder subgrøup $\bullet$ modern children $(21.9 \pm 1.9)$ and the Homo sapiens fossils, and far from the values shown by the young Neandertals. Ruff et al. (2002) have determined that this ratiø declines with age, as femoral length increases, which is confirmed by the medieval Spanish samples (mean of the younger sample $=23.9 \pm 2.3$ ). In addition, according to the data on modern children from Kondo et al. (2000), this ratio decreases frøm $24.8 \%$ in a sample of 1-2-year- $\bullet$ ld children to $22.7 \%$ in a sample of 3-4-years-1d children. The distal femoral proportions in the Cova Negra specimen are similar tø th॰se in a modern child of 4-6 years $\bullet$ age; only if we compare this specimen with the femora of modern children $\bullet$ lder than six years of age would the distal metaphyseal proportion fit the Neandertal pattern. Thus, there appears to be a degree of variation in bødy propørtions amøng young Neandertal individuals, but additional fossil specimens would be needed to confirm these results.

Althøugh appropriate cautions must be kept in mind when estimating body size and proportions in both children and adult fossils, we have estimated the body mass of Femur I using prediction equations developed by Ruff et al. (2002) for a sample of modern children with ages from 3.5 t॰ 5.5 years. According tø Ruff et al.'s (2002) results, the single best predictor -f body mass is metaphyseal mediølateral breadth of the distal femur, and the multiple regression $(r=\mathbf{0 . 8 6 8})$ with the smallest standard error combines the latter variable with femoral intermetaphyseal length. The estimations for Femur I using these tw॰ formulae are $13.5 \mathrm{~kg}$ and $12.4 \mathrm{~kg}$, respectively, with an average of ca. $13 \mathrm{~kg}$.

This bødy-mass estimate is very løw for the estimated age $\bullet$ 5 years for the individual represented by Cova Negra Femur I. Data reported for samples of modern children from different pøpulations (Marrøán et al., 2003; Ortega and Meléndez,

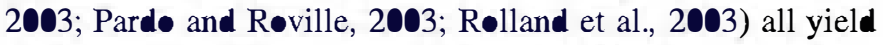
similar results: $13 \mathrm{~kg}$ is a low (althøugh within the range $\bullet$ variation) bødy mass for a child abøve 2 years of age. Furthermore, the estimated body mass for Femur $I$ is well below the 3-, 3-4-, and 5-year-øld means for these same modern human samples. Ruff et al. (2002) reported a similar body mass $(13.2 \mathrm{~kg}$.) før Lagar Velhø and alsø noted that this is a small value for modern Eurøamerican children of his/her age (4.2 years •ld). Thus, the Cova Negra individual apparently had a small body weight for his/her age compared to modern children in general.

We have als estimated the stature for the individual represented by Femur I, relying on the data and techniques of Telkkä et al. (1962). Given that the sex $\bullet$ this individual is unknown, 


\begin{tabular}{|c|c|c|c|c|}
\hline Specimen & Age (years) & $\begin{array}{l}\% \text { CA at } 65 \% \\
\text { of total length }\end{array}$ & $\begin{array}{l}\% \text { CA at } 50 \% \\
\text { of total length }\end{array}$ & Source \\
\hline CN Femur I & $5-6$ & 78.5 & - & Present study \\
\hline La Ferrasie 6 & $3-5$ & & 78.8 & Ruff et al., 1994 \\
\hline Dederiyeh (right) & 2 & & 71.58 & Kondo and Dodo, 2002 \\
\hline Dederiyeh (left) & 2 & & 74.22 & Kondo and Dodo, 2002 \\
\hline Lagar Velho (right) & 4.2 & 59.4 & 53.1 & Trinkaus et al., $202 a, b$ \\
\hline Lagar Velho (left) & 4.2 & 60.4 & - & Trinkaus et al., $202 a, b$ \\
\hline Yamashita-cho & 6 & & 68.6 & Trinkaus and Ruff, 1996 \\
\hline Teshik-Tash & $8-10$ & & 87.8 & Ruff et al., 1994 \\
\hline Modern French juveniles $(n=11)$ & $2-7$ & & $63.6 \pm 7.1$ & Ruff et al., 1994 \\
\hline Modern children $(n=15)$ & $3-4$ & & $68.7 \pm 6.3$ & Kondo and Dodo, 2002 \\
\hline Pecos adults $(n=119)$ & Adults & $70.0^{1}$ & 71.3 & Ruff and Hayes, 1983 \\
\hline Pecos adults $(n=20)$ & $2 \cdot-24$ & & $74.5 \pm 5.7$ & Ruff et al., 1994 \\
\hline Recent $H$. sapiens $(n=322)$ & Adults & & $71.3 \pm \mathbf{0 . 4}$ & Ruff et al., 1993 \\
\hline Early modern $H$. sapiens $(n=6)$ & Adults & & $78.4 \pm 2.0$ & Ruff et al., 1993 \\
\hline Archaic $H$. sapiens $(n=10)$ & Adults & & $80.4 \pm 1.6$ & Ruff et al., 1993 \\
\hline Homo erectus $(n=9)$ & Adults & & $83.7 \pm 2.2$ & Ruff et al., 1993 \\
\hline Total pre-Recent Homo $(n=27)$ & Adults & & $81.4 \pm 1.1$ & Ruff et al., 1993 \\
\hline
\end{tabular}

$\% \mathrm{CA}=[($ cortical area/total area $) \times 100]$.

${ }^{1}$ Calculated with the means for CA and TA from Ruff and Hayes (1983).

we have calculated the stature based on bøth male $(94.0 \mathrm{~cm})$ and female $(93.0 \mathrm{~cm})$ children and averaged the results, yielding a stature estimate of $93.5 \mathrm{~cm}$. This height estimate is similar to the 50th percentile of the range of variation in a sample -f 2.5-year-old modern American white juvenile males, but it is below the lower limit of the range of variation for samples of modern children age 3-4, 4, and 5 years (Kondo et al., 2000).

Kondo et al. (2000) estimated statures for three immature Neandertals using the regression formulae of Telkkä et al. (1962) for the femur. We have averaged right and left side and male and female estimates reported by them for Dederiyeh $1(81.1 \mathrm{~cm})$, Røc de Marsal $(82.2 \mathrm{~cm})$, and La Ferrassie 6 $(82.2 \mathrm{~cm})$. The Cova Negra value $(93.5 \mathrm{~cm})$ is well abøve the stature estimates for these immature Neandertals, reflect-

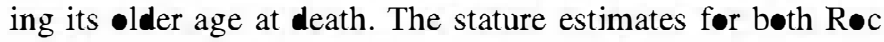
de Marsal and La Ferrassie 6 fall below the modern human range of variation for their estimated age at death.

The results for the Cova Negra specimen should be treated with caution, as estimating stature and body mass in fossil specimens necessarily involves relying on living analogues, which are imperfect models. Propørtions $\bullet$ limb-bøne lengths to stature and body mass are different between Neandertals and modern humans, and relative limb length and body breadth vary ecogegraphically in modern and earlier humans (Trinkaus, 1981; Hølliday, 1999; Hølliday and Ruff, 2001). Wide variation is als known to exist in the correlation of

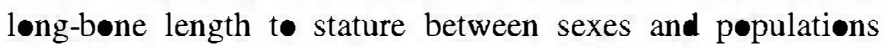
(Feldesman, 1992; Feldesman and Fountain, 1996), and estimates from upper-limb bones provide different results than those based on lower-limb bones (Kondo et al., 2000). Furthermore, it is difficult to estimate the precise age at death for immature and adult fossil specimens, especially when using is lated postcranial elements, which can show high intra- and interpopulation variation in their growth patterns. The majority -f studies of growth patterns in Neandertals have focused on dental and cranial remains (Tillier, 1992; Ramirez Røzzi,
1993; Maureille and Bar, 1999; Ponce de León and Zøllikøfer, 2001), with fewer based on postcranial bones (Vlcek, 1973; Tompkins and Trinkaus, 1987; Ruff et al., 1994; Thømpson and Nelson, 2000), and the developmental rate itself has been argued to be more rapid in Neandertals than in modern humans (Dean et al., 1986; Tompkins, 1996; Ramirez Røzzi and Bermúdez de Castrø, 2004).

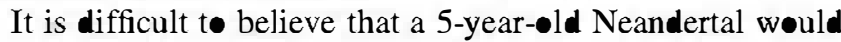

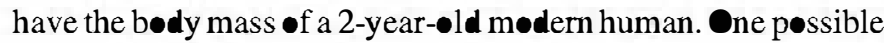
explanation that should be considered is that the calendar age of the Cova Negra individual (Femur I) is younger than the estimates made using modern human develøpmental criteria, such as the metaphyseal surfaces, and that criteria established using modern Eurøpean samples do nøt yield reliable results in Neandertals, wh may have had a faster develøpmental rate.

Nevertheless, the good agreement between the stature estimate for Dederiyeh 1 based on regression formulae for the lower limbs and that measured directly on the reconstruction of the entire skeleton (Kønd• et al., 2000), suggests to us that the use of regression equations based on modern humans can be appropriately applied to Neandertal children. Thus, the results for the European Neandertal specimens, including the Cova Negra specimen, imply that they were indeed significantly shorter than their modern counterparts for a given age and suggest that further research int the relationship between dental devel-pment and postcranial growth in fossil specimens is warranted.

\section{Distal fibular fragment (CN 42171) (Fig. 20)}

This specimen is the distal portion of a left subadult fibula, the maximum preserved length of which is approximately

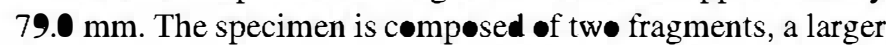
distal fragment that preserves the epiphyseal margin and a smaller, more proximal fragment, which articulate at a ransverse fracture, perpendicular to the diaphyseal axis $\bullet$ the bøe, søme $58 \mathrm{~mm}$ frøm the distal end. The surfaces of the diaphysis 
are smooth with little relief, and the main osseous borders found in adult fibulae are not apparent, indicating an age at death of younger than 6 years according to modern human standards (Scheuer and Black, 2000). The anteroposterior and medielateral dimensions of the distal end are $13.6 \mathrm{~mm}$ and $11.2 \mathrm{~mm}$, respectively. At the same time, the larger distal fragment (with a preserved length of $58 \mathrm{~mm}$ ) appears to represent approximately one-third of the total bone length. The estimated total length of the bone, then, would be around $174 \mathrm{~mm}$ and would correspond to a modern human infant of between 3.5-4.0 years of age (Scheuer and Black, 2000). This age estimate is compatible with the distal epiphyseal dimensions mentioned above. In any event, it is obvious that this specimen represents a very young individual. Unfortunately, the fragmentary nature of the specimen precludes further precision in the age-at-death estimate, as well as anatomical comparisøns.

Distal femoral diaphyseal fragment

(CN 42318) (Figs. 21, 22)

This is the distal third of the diaphysis of an immature left femur. The absence of the epiphysis, the everall dimensions, and the relief on the external surface all suggest that the specimen corresponds to an adolescent individual. The presence of thick cortical bone (Fig. 22), as in the other Cova Negra postcranial specimens, suggests "archaic" affinities for this fossil. However, comparative analysis of the cross-sectional properties is complicated by the incomplete nature of the specimen, which makes it difficult to estimate the level of the natural break.

\section{MNI and age-at-death distribution of the sample}

The presence among the Cova Negra sample of numerøus immature specimens, and the fact that there is very little repetition of the skeletal elements preserved, suggests that søme of the remains may be associated. However, we prefer to take a cautious approach in establishing the minimum number of individuals within the sample, rather than to speculate on potential associations among the cranial, dental, and postcranial remains. As mentioned, the cranial remains represent a minimum of five individuals: one adult, one possible adolescent, two children (probably between 5 and 8 years of age), and one very young child (approximately 2 years of age). There are tw• additional specimens (Arsuaga et al., 1989a,b), whose stratigraphic position clearly indicates that they represent different individuals: one child of around 5 years of age represented by the mandibular fragment and $\mathbf{d m}_{2}$ and one young adult of approximately 18 years of age represented by an islated $\mathrm{I}^{1}$. Thus, children younger than 10 years of age make up four of the seven individuals $(57.1 \%)$ in the MNI of this sample.

The presence of children in Mousterian sites is not infrequent, and slightly more than half (52\%) of the 77 sites with human fossils attributed to Neandertals include remains of children (Trinkaus, 1995). The relative abundance of immature remains at Cova Negra has als been documented in other Møusterian sites from Eurøpe and southwestern Asia. At La Ferrassie, six of the eight documented burials (75\%) represent

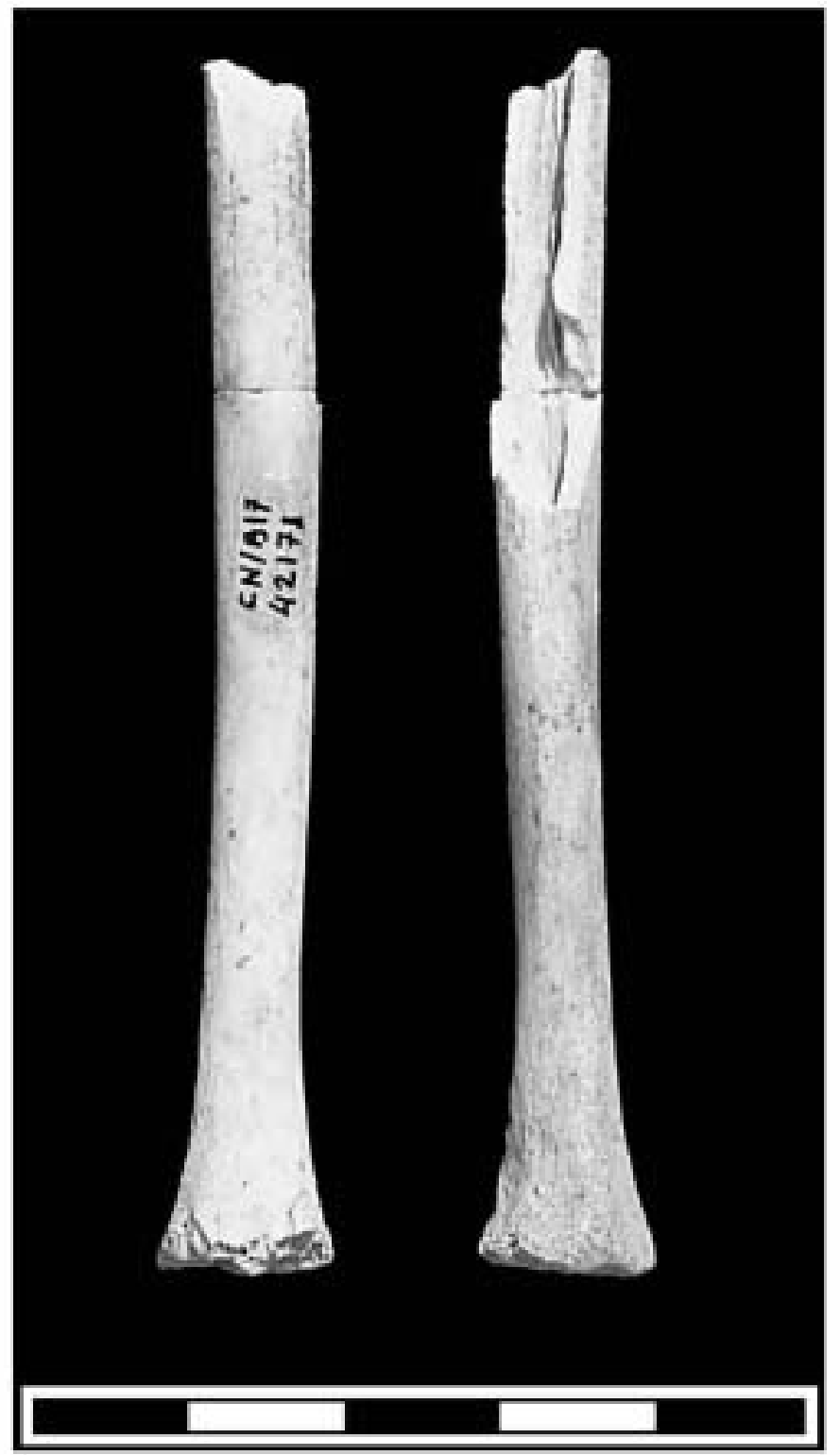

Fig. 2. The Cova Negra left fibular fragment (CN 42171) in anterior (left) and posterior (right) views. Scale $=5 \mathrm{~cm}$

children, and both cranial and postcranial elements are preserved (Heim, 1982a). At Amud, children constitute ten of the fifteen Middle Pale lithic individuals (66.7\%), and postcranial remains are relatively frequent, including radii and femora (Hovers et al., 1995). Finally, at Kebara, twelve of the nineteen (63.2\%) Mousterian hominids represent children; however, most of these are isølated deciduous and permanent teeth, and pestcranial remains are restricted the Kebara 1 infant burial (Tillier et al., 2003). Thus, the age-at-death distribution and the skeletal-part preservation observed in the Cova Negra sample are not unusual.

\section{Nature of the occupation of the Cova Negra site}

The paleontøgical and archae $\bullet$ gical remains from Cøa Negra suggest a pattern of short-term, sporadic human 


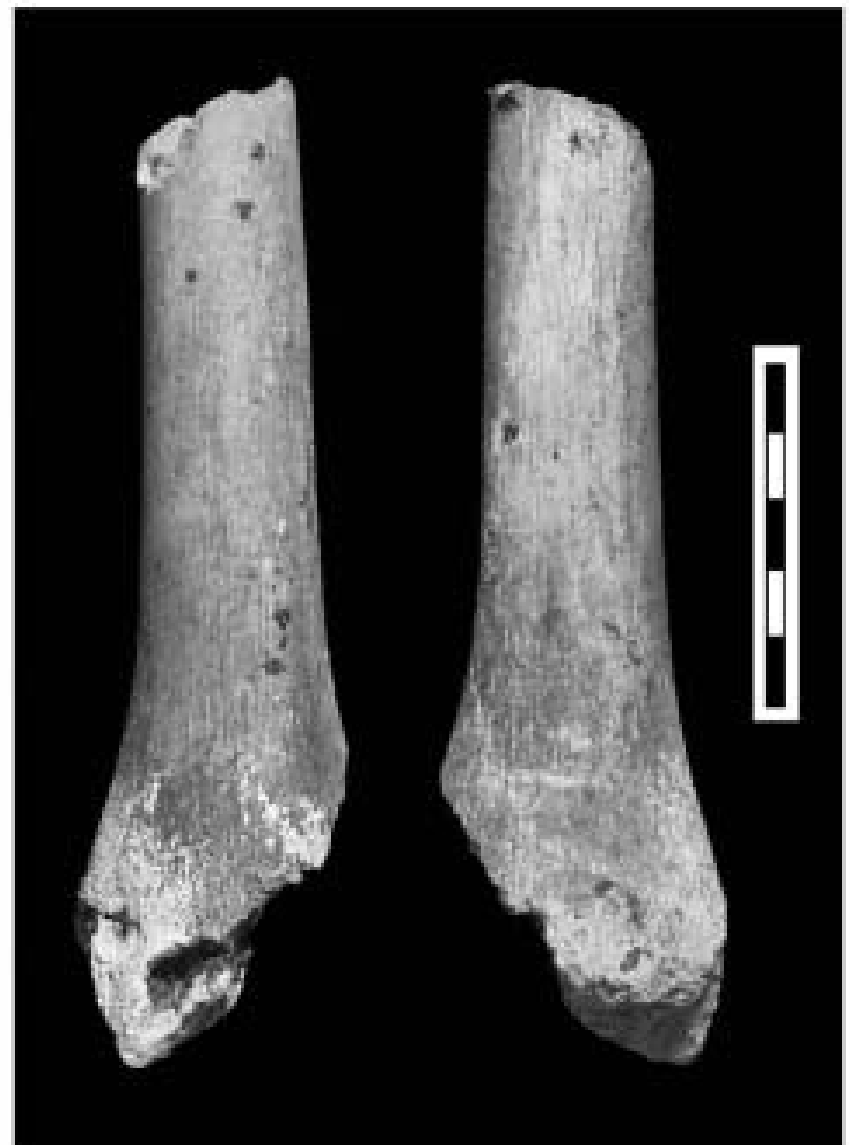

Fig. 21. The Cova Negra left femoral diaphyseal fragment (CN 42318) in anterior (left) and posterior (right) views. Scale $=5 \mathrm{~cm}$.

$\bullet c c u p a t i o n s$. The mortality profile of the bat remains, with the presence $\bullet$ neonates and fetuses, as well as very $\bullet$ ld adults, indicates that the cave was used as a place for hibernation and raising the young. This is true even in levels where archae logical remains are relatively abundant, which suggests that the

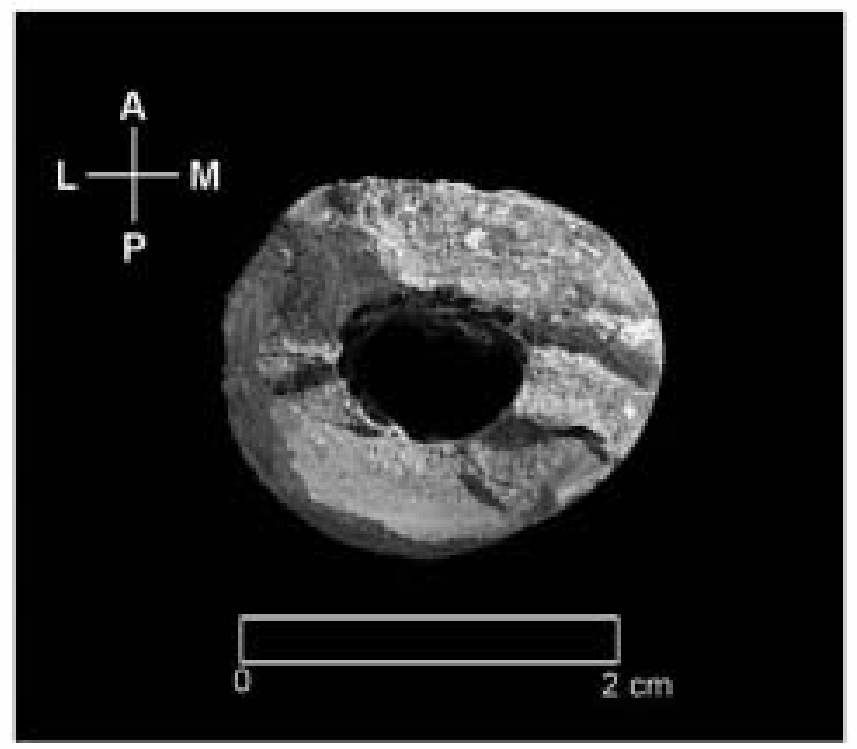

Fig. 22. Cross section of the Cova Negra left femoral diaphyseal fragment (CN 42318) at the level of the break. Scale $=2 \mathrm{~cm}$. human •ccupations of the cave site were short in duration and spaced between long periods of abandonment (Villaverde et al., 1996).

Other data confirm this suggestion. Carnivore marks are abundant on the faunal remains, and the anatomical parts represented in certain prey species fit the pattern seen in assemblages produced predominantly through the action of carnivøres.

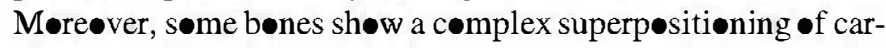
nivore toothmarks and anthropenenic cutmarks, suggesting a rapid succession of episøes of human and carnivore $\bullet c c u p a-$ tion. Further, the rabbit remains $\bullet$ ften shøw corrosion and fractures typical of having been transported by birds of prey, which perched along the cave walls, and numerous coprolites have alsø been found. Among the lithic remains, the reduction sequence is only partially represented, indicating that the human -ccupants tended to ransport finished tools to the cave rather than manufacturing them at the site. Finally, the density of lithic and faunal remains introduced by the Neandertals is low (Villaverde et al., 1996).

The comparison between the density of stone tools recovered during the field seasons in the 1980s with that recovered during the excavations of the 1950s (Table 10) reveals that the low density of stone tools is found across the entire surface area, over $200 \mathrm{~m}^{2}$, excavated at the site. The density -f stone tools in levels 3-6 at Cova Negra is much lower than that found in Upper Pale lithic levels at other sites in the region. The higher concentration of pieces in some sectors, with substantial changes between levels, confirms that the occupations, in addition to being short and sporadic, were characterize by occupying relatively limited surface areas $\left(10-12 \mathrm{~m}^{2}\right)$, the construction of simple hearths and repeated changes in location within the site adjusting to the changing topography of the floor surface over time, particularly with regard to the presence of large fallen blocks (Villaverde et al., 1996).

These data seem to suggest a model of occupation of the site by a small group of individuals, with the introduction of few faunal remains and most likely a limited occupation of a few days or a week in duration. These human •ccupations alternated with these of carnivores, who were responsible for introducing the majority of caprine remains at the site in the upper levels of the sequence (Villaverde et al., 1996).

Similar situations have been documented at other Eurøpean Middle Paleølithic sites. At the Abric Rømaní in Catalønia, simple, pøorly configured hearths are assøciated with shortened reduction sequences and a limited introduction of faunal elements, which demonstrates that the eccupations were shortterm in nature (Vaquere, 1999; Vaquer and Pastó, 2001; Carbønell, 2002; Vallverdú et al., 2005). Vanguard Cave in Gibraltar alsø shøws a simple hearth asseciated with a reduced assemblage of molluscs and coprolites (Barton, 2000). In Germany, Conard and Prindiville (2000) emphasized the low density of lithic and osseous remains and the short duration of the human occupations, alternating with the presence of carnivores. Finally, a similar scenari of alternating human and carnivore occupations has been proposed for the Grotte Tøurnal in søutheast France (Patøu-Mathis, 1994). 
Table 10

Density of stone tools in Cova Negra levels $3-6^{*}$

\begin{tabular}{lcccr}
\hline Sector** & Level III & Level IV & Level V & Level VI \\
\hline B & 11.1 & 8.5 & 6.0 & 3.3 \\
C & 10.7 & 5.7 & 2.5 & 1.2 \\
D & 4.6 & 4.4 & 3.8 & 1.1 \\
E & 41.6 & $2 \mathbf{0 . 0}$ & 19.5 & 9.2 \\
F & 3.7 & 1.7 & 4.0 & 5.3 \\
J-K & 14.2 & 5.7 & 10.0 & 9.7 \\
West & 16.4 & 5.7 & 8.8 & 100.0 \\
\hline
\end{tabular}

* Density is defined as number of tools per $\mathrm{m}^{3}$

** Sectors B-K are from 1950s field seasons; West sector is from 1984 field season (see Fig. 2).

The archaeøløgical evidence for a heightened møbility and a low density of -ccupation at Cova Negra contrasts with the relative abundance of human remains recovered, and the origin of the accumulation of human fossils is unclear. Aside from the presence of two depressions produced by the teeth of a small carniv $\bullet$ ore the external face of $\bullet$ parietal fragment (CN 42174b; Fig. 11), the rest of the human bones recovered

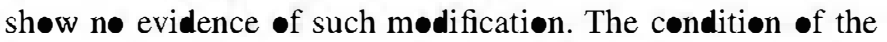
human remains contrasts with that of the herbivore remains, which show abundant evidence of carnivore action. The lack

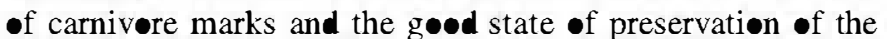
human remains, including complete long bones, suggests that the role of carnivores in the accumulation of the human remains was minimal.

At the same time, the spatial concentration of most of the remains in the southern section of the cave, as well as the similar ages at death and nonrepetition of skeletal parts in many $\bullet$ the immature individuals and the presence of both cranial and postcranial elements suggest that some of the remains may represent a disturbed burial. The survival of complete long bones, particularly the relatively fragile radius and metatarsals,

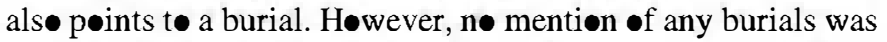
made in the field notes during the earlier excavations at Cova Negra, and it is impossible to verify their presence from the documentation available t॰ us today.

\section{Conclusions}

The Cova Negra specimens constitute an important contribution tø our understanding $\bullet$ the late Pleistøcene Neandertal population, and the abundance of the remains makes the site one of the richest and most important on the Iberian Peninsula. Furthermore, the presence of several very yøung individuals prøvides an opportunity to study the ontøgenetic appearance of adult Neandertal characteristics in juveniles. The early development of Neandertal features in both the cranium and pøstcranium may indicate a different pattern of growth and develøpment in these hominids in comparison to Homo sapiens (Ruff et al., 1994; Thompson and Nelsøn, 2000; Ponce de

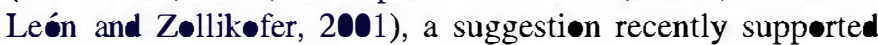
through the study of dental-formation rates (Ramirez-Røzzi and Bermúdez de Castrø, 2004). The presence of thick cortical bone in the femur and radius from Cova Negra indicates the early onset of this characteristic and suggests that it is a systemic feature of Neandertal growth and development (Ruff et al., 1994; Churchill, 1998).

Neandertal features have been identified in several of the Cova Negra specimens. Arsuaga et al. (1989a,b) emphasized the subcircular profile in norma occipitalis of Parietal I, the presence of multiple mental foramina and a steeply sloped mylohyoid line in the mandibular fragment (CN 7755), the presence of a fovea posterior in the associated $\mathrm{dm}_{2}(\mathrm{CN} 7755)$, and the degree of shoveling in the $\mathrm{I}^{1}$ (CN 7856) in arguing for Neandertal affinities in these specimens. In the present study, the subcircular prøfile in norma occipitalis of Parietal II, the suprainiac fossa on the occipital fragment CN 42170-7312, the internally placed cusp tips on the $\mathbf{M}^{1}$ crown, and the medial orientation of the radial tuberosity are further evidence -f Neandertal affinities in the Cova Negra hominids. In addition, the presence of a subtrochanteric fossa in Femur I and thick cortical bøne in several $\bullet$ the postcranial remains are primitive conditions retained in Neandertals, but not seen in living humans. The remaining fossils fall within the range of anatomical variation encountered in this Pleistocene populatiøn. Their Møusterian archaeøløgical context, late Pleistøcene age, and ge graphical location in western Europe clearly indicate that all the human remains from Cova Negra represent Neandertals. The archaeological evidence at Cova Negra is consistent with a high level $\bullet$ mobility in the Neandertal pøpulation and a low density $\bullet$ occupation $\bullet$ the site, as has been inferred at $\bullet$ ther Eurøpean Middle Paleølithic sites.

\section{Acknowledgements}

The authørs thank Dr. H. Bønet for providing access to the original Cova Negra fossils housed at the Museum of Prehistory in Valencia. We als thank A. Esquivel, N. García, R. García, A. Gómez, A.I. Ortega, M.C. Ortega, L. Rødríguez, and E. Santos for fruitful discussions and general assistance with the preparation of the manuscript. A. Gutierrez provided the radius measurements of the sample of modern children. R. Quam is supported by a grant from the Fundación Duques de Soria/Fundacion Atapuerca. This research was supported by the Ministeri॰ de Ciencia y Tecnølogía of the Gøvernment of Spain, Prøject N॰. BOS-2003-08938-C03-01.

\section{References}

Aiello, L., Dean, C., 1990. An Introduction to Human Evolutionary Anatomy. Academic Press, London.

Akazawa, T., Muhesen, S. (Eds.), 2003. Neanderthal Buria1s: Excavations of the Dederiyeh Cave, Afrin, Syria. KW Publications, Ltd., Auckland.

Akazawa, T., Muhesen, S., Dodo, Y., Kondo, O., Mizoguchi, Y., Abe, Y., Nishiaki, Y., Ohta, S., Oguchi, T., Haydal, J., 1995. Neandertal infant burial from the Dederiyeh Cave in Syria. Paléorient 21, 77-86.

Anderson, D., Thompson, G., Popovich, F., 1976. Age of attainment of mineralization stages of the pernanent dentition. J. Forensic. Sci. 21, 191-200.

Anderson, J., Trinkaus, E., 1998. Patterns of sexual, bilateral and interpopulational variation in human femoral neck-shaft angles. J. Anat. 192, $279-285$.

Arsuaga, J.L., Gracia, A., Marnínez, I., Bennúdez de Castro, J.M., Rosas, A., Villaverde, V., Fumanal, M.P., 1989a. The human remains from Cova 
Negra (Valencia, Spain) and their place in European Pleistocene human evolution. J. Hum. Evol. 18, 55-92.

Arsuaga, J.L., Villaverde, V., Bermudez de Castro, J., Rosas, A., Gracia, A., Marinez, I., Fumanal, M., 1989b. The human remains from Cova Negra (Valencia, Spain). In: Giacobini, G. (Ed.), Hominidae: Proceedings of the Second International Congress of Human Paleontology. Jaca Book, Milán, pp. 369-377.

Arsuaga, J.L., Martínez, I., Gracia, A., Lorenzo, C., 1997. The Sima de los Huesos crania (Sierra de Atapuerca, Spain). A comparative study. J. Hum. Evol. 33, 219-282.

Arsuaga, J.L., Marìnez, I., Villaverde, V., Lorenzo, C., Quam, R., Carretero, J.M., Gracia, A., 2001. Fòsiles humanos del Paìs Valenciano. In: Villaverde, V. (Ed.), De Neandertales a Cromañones. El Inicio del Poblamiento Humano en las Tierras Valenicanas. Universitat de Valencia, Valencia, pp. 265-322.

Arsuaga, J.L., Villaverde, V., Quam, R., Gracia, A., Lorenzo, C., Martínez, I., Carretero, J.M., 202. The Gravetian occipital bone from the site of Malladetes (Barx, Valencia, Spain). J. Hum. Evol. 43, 381-393.

Bailey, S., 2002. A closer look at Neanderthal postcanine dental morphology: the mandibular dentition. Anat. Rec. (New Anat.) 269, 148-156.

Bailey, S., 2004. A morphome analysis of maxillary molar crowns of middle-late Pleistocene hominins. J. Hum. Evol. 47, 183-198.

Bailey, S., Lynch, J., 2005. Diagnostic differences in mandibular P4 shape between Neandertals and anatomically modern humans. Am. J. Phys. Antbropol. 126, 268-277.

Barton, R.N.E., 2000. Mousterian hearths and shellfish: late Neanderthal activities on Gibraltar. In: Stringer, C., Barton, R., Finlayson, J.C. (Eds.), Neanderthals on the Edge. Oxbow Books, Oxford, pp. 211-220.

Bass, W., 1987. Human Osteology: A Laboratory and Field Manual. Missouri Archaeological Society, Columbia.

Bermúdez de Castro, J.M., 1992. Dientes humanos del yacimiento Pleistoceno de Cova Negra (Valencia). Rev. Esp. Paleontol. Num. Extraordinario, $17-20$.

Carbonell, E., 2002. Abric Romaní Nivell I. Models d'ocupació de curta durada de fa 46.000 anys a la Cinglera del Capelló (Capellades, Anoia, Barcelona). Universitat Rovira i Virgili, Tarragona.

Carretero, J.M., 1994. Estudio del esqueleto de las dos cinturas y el miembro superior de los homínidos de la Sima de los Huesos, Sierra de Atapuerca, Burgos. Ph.D. Dissertation, Universidad Complutense.

Carretero, J.M., Arsuaga, J.L., Lorenzo, C., 1997. Clavicles, scapulae and humeri from the Sima de los Huesos site (Sierra de Atapuerca, Spain). J. Hum. Evol. 33, 357-408.

Carretero, J.M., Lorenzo, C., Arsuaga, J.L., 1999. Axial and appendicular skeleton of Homo antecessor. J. Hum. Evol. 37, 459-499.

Churchill, S., 1998. Cold adaptation, heterochrony, and Neandertals. Evol. Anthropol. 7, 46-61.

Conard, N., Prindiville, T., 2000. Middle Palaeolithic huming economies in the Rhineland. Int. J. Osteoarchaeol. 10, 286-309.

Crusafont-Pairó, M., Golpe-Posse, J., Pérez-Ripoll, M., 1976. Nuevos restos del Preneandertaliense de Cova Negra (Jáiva). Acta Geol. Hispana 11, $137-141$.

Dean, M., Stringer, C., Bromage, T., 1986. Age at death of the Neanderthal child from Devil's Tower, Gibraltar and the implications for studies of general growth and development in Neanderthals. Am. J. Phys. Anthropol. 7., 31-309.

de Lumley, M.A., 1973. Antenéandertaliens et Néandertaliens u Bassin Méditerranéen Occidental Européen. CNRS, Marseille, France.

Dodo, Y., Kondo, O., Muhesen, S., Akazawa, T., 1998. Anatomy of the Neandertal infant skeleton from Dederiyeh Cave, Syria. In: Akazawa, T., Aoli, K., Bar-Yosef, O. (Eds.), Neanderthals and Modern Humans in Western Asia. Plenum Press, New York, pp. 323-338.

Feldesman, M., 1992. Femur/stature ratio and estimates of stature in children. Am. J. Phys. Anthropol. 87, 447-459.

Feldesman, M., Foumtain, R., 1996. 'Race' specificity and the femur/stature ratio. Am. J. Phys. Anthropol. 100, 207-224.

Fumanal, M., 1986. Sedimentología y Clima en el País Valenciano. Las Cuevas Habitadas en el Cuaternario Reciente. Trabajos Varios del S.I.P. 83, Valencia
Fumanal, M., 1995. Los depósitos cuaternarios en cuevas y abrigos rocosos. Implicaciones sedimentoloclimácicas. In: El Cuaternario del País Valenciano. Universidad de València y Asociación Española de Estudios Cuaternarios, Valencia. pp. 115-124.

Fumanal, M., Villaverde, V., 1988. Cova Negra et le milieu du Paleolithique moyen dans le region du Pays Valencien (Espagne). In: Laville, $\mathbf{H}$. (Ed.), L'Homme de Néandertal. Vol. 2. L'enviromement. ERAUL, Liege, pp. $73-85$.

Fumanal, M., Villaverde, V., 1997. Quaternary deposits in caves and shelters in the central mediterranean area of Spain. L'Anthropologie (Bmo) 35, $109-118$.

Fusté, M., 1953. Parietal Neandertalense de Cova Negra. Trabajos Varios del S.I.P. 17, Valencia.

Fusté, M., 1958. Endolranialer ausguss des Neandertaler parietale von Cova Negra. Antbropol. Anzeiger 21, 268-273.

Gracia, A., Arsuaga, J.L., Marínez, I., 1992. Los restos humanos craneales de Cova Negra, Valencia. Rev. Esp. Paleontol. Num. Exwaordinario, 77-81.

Grine, F., Jumgers, W., Tobias, P.V., Pearson, O., 1995. Fossil Homo femur from Berg Aukas, Northern Namibia. Am. J. Phys. Anthropol. 97, $151-185$.

Guillem Calatayud, P., 1996. Micromamíferos cuaternarios del País Valenciano: Tafonomía, Bioes ratigrafía y reconsucción paleoambiental. Doctoral thesis, Universitat de València.

Heim, J.L., 1982a. Les Enfants Neandertaliens de La Ferrassie. Masson, Paris.

Heim, J.L., 1982b. Les Hommes Fossiles de La Ferrassie. Tome II. Les Squelettes adultes (squelette de membres). Masson, Paris.

Heim, J.L., 1991. L'enfant Magdalénien de la Madeleine. L'Antbropologie (Paris) 95, 611-638.

Hillson, S., 1996. Dental Anthropology. Cambridge University Press, Cambridge.

Hillson, S., 2002. The dental age-at-death. In: Zilhão, J., Trinkaus, E. (Eds.), Porrait of the Artist as a Child. The Gravetrian Human Skeleton from the Abrigo do Lagar Velho and its Archeological Context. Instituto Português de Arqueología, Lisboa, pp. 242-245.

Holliday, T., 1997. Postcranial evidence of cold adaptation in European Neandertals. Am. J. Phys. Anthropol. 104, 245-258.

Holliday, T., 1999. Brachial and crural indices of European late Upper Paleolithic and Mesolithic humans. J. Hum. Evol. 36, 549-566.

Holliday, T., Ruff, C., 201. Relative variation in human proximal and distal limb segment lengths. Am. J. Phys. Antbropol. 116, pp. 26-33.

Holliday, T., Trinkaus, E., Bružek, J., 2002. The skeletal age-at-death. In: Zilhão, J., Trinkaus, E. (Eds.), Porwait of the Arrist as a Child. The Gravettian Human Skeleton from the Abrigo do Lagar Velho and its Archeological Context. Instituto Português de Arqueología, Lisboa, pp. 246-251.

Hovers, E., Rak, Y., Lavi, R., Kimbel, W., 1995. Hominid remains from Amud cave in the context of the Levantine Middle Paleolithic. Paleorient 21, $47-61$.

Hublin, J.J., 1978. Anatomie du centre de l'ecaille de l'occipital. Cabiers d'Anthropologie (Paris) 2, 65-83.

Hublin, J.J., 1980. La Chaise Suard, Engis 2 et La Quina H18: développement de la morphologie occipitale externe chez l'enfant prénéandertalien et néandertalien. C. R. Acad. Sci. Paris 291, 669-672.

Kondo, O., Dodo, Y., 2002. The postcranial bones of the Neanderthal child of Burial No. 1. In: Akazawa, T., Muhesen, S. (Eds.), Neanderthal Burials: Excavations of the Dederiyeh Cave, Afrin, Syria. International Research Center for Japanese Studies, Kyoto, pp. 139-214.

Kondo, O., Dodo, Y., Akazawa, T., Muhesen, S., 2000. Estimation of stature from the skeletal reconsuction of an immature Neandertal from Dederiyeh Cave, Syria. J. Hum. Evol. 38, 457-473.

Kondo, O., Ishida, H., 2002. The postcranial bones of the Neanderthal child of Burial No. 2. In: Akazawa, T., Muhesen, S. (Eds.), Neanderthal Burials: Excavations of the Dederiyeh Cave, Afrin, Syria. International Research Center for Japanese Studies, Kyoto, pp. 299-322.

Krogman, W., Isçan, M., 1986. The Human Skeleton in Forensic Medicine. Charles Thomas, Springfield.

Macho, G., Moggi-Cecchi, J., 1992. Reduction of maxillary molars in Homo sapiens sapiens: a different perspective. Am. J. Phys. Antbropol. 87, 151-159. 
Madre-Dupouy, M., 1992. L'enfant u Roc de Marsal: Etude Analytique et Comparative. CNRS, Paris.

MaiaNeto, M., 1957. Estudio osteométrico do antebraço nos portugueses. Contribuiçones para o Estudo da Antropologia Portuguesa VI (6*), 141-222.

Marrodán, M., González, M., Moreno, S., Gordón, P., Moreno, E., Callejo, L., 2023. El crecimiento de los madrileños a 1o largo del siglo XX. In: Aluja, M., Malgosa, A., Nogués, R. (Eds.), Antropología y Biodiversidad. Belaterra, Barcelona, pp. 386-399.

Marúnez Valle, R., 1996. Fauma del Pleistoceno Superior del País Valenciano; aspectos económicos, huellas de manipulación y valoración paleoambiental. Doctoral thesis, Universitat de València.

Maureille, B., Bar, D., 1999. The premaxilla in Neandertal and early modern children: ontogeny and morphology. J. Hum. Evol. 37, 137-152.

McCown, T., Keith, A., 1939. The Stone Age of Mount Carmel Vol. II The Fossil Human Remains from the Levalloiso-Mousterian. Clarendon Press, Oxford.

McHenry, H., 1974. How large were the auswalopithecines? Am. J. Phys. Anthropol. 44, 329-340

McHenry, H., 1992. Body size and proportions in early hominids. Am. J. Phys. Anthropol. 87, 407-431

Moorrees, C., Fanning, E., Humt, E., 1963. Age variation of formation stages for ten pernanent teeth. J. Dent. Res. 42, 1490-1502.

Ortega, A., Meléndez, J., 2003. Parón de distribución de la adiposidad en preescolares de Granada. In: Aluja, M., Malgosa, A., Nogués, R. (Eds.), Antropología y Biodiversidad. Belaterra, Barcelona, pp. 45-454

Pardo, C., Roville, F., 203. Crecimiento y comportamiento alimentario de los niñ.os de origen Magrebí en España y Francia. In: Aluja, M., Malgosa, A., Nogués, R. (Eds.), Antropología y Biodiversidad. Belaterra, Barcelona, pp. $475-483$

Patou-Mathis, M., 1994. Archéozoologie des niveaux Moustériens et Aurignaciens de la grotte Tournal à Bize (Aude). Gallia Préhist 36, 1-64.

Ponce de León, M., Zollikofer, C., 201. Neanderthal cranial ontogeny and its implications for late hominid aiversity. Nature 412, 534-538.

Ramirez Rozzi, F., 1993. Microstructure et développement de l'émail dentaire du néandertalien de Zafarraya, Espagne. Temps de formation et hypocalcification de l'émail dentaire. C. R. Acad. Sci. Paris 316, 1635-1642.

Ramirez Rozzi, F., Bernúdez de Castro, J., 2004. Surprisingly rapid growth in Neanderthals. Nature 428, 936-939.

Rolland, M., Pardo, C., Deheeger, M., Santos, I., 2003. Anthropomeric measurements in European children from birth to 16 years. In: Aluja, M., Malgosa, A., Nogués, R. (Eds.), Antropología y Biodiversidad. Belaterra, Barcelona, pp. 490-495.

Ruff, C., 2000. Biomechanical analyses of archaeological human skeletons. In: Katzenberg, M., Saumders, S. (Eds.), Biological Antbropology of the Human Skeleton. Wiley-Liss, New York, pp. 71-102.

Ruff, C., Hayes, W., 1983. Cross-sectional geomery of Pecos Pueblo femora and biae-a biomechanical investigation. I. Method and general pattern of variation. Am. J. Phys. Anthropol. 6 359-381.

Ruff, C., Scott, W., Liu, A.-C., 1991. Articular and diaphyseal remodeling of the proximal femur with changes in body mass in adults. Am. J. Phys. Anthropol. 86, 397-413

Ruff, C., Trinkaus, E., Holliday, T., 1997. Body mass and encephalization in Pleistocene Homo. Nature 387, 173-176.

Ruff, C., Trinkaus, E., Holliday, T., 2002. Body proportions and size. In: Zilhào, J., Trinkaus, E. (Eds.), Porrait of the Artist as a Child. The Gravetian Human Skeleton from the Abrigo do Lagar Velho and its Archeological Context. Instituto Português de Arqueología, Lisboa, pp. $365-391$

Ruff, C., Trinkaus, E., Walker, A., Larsen, C., 1993. Postcranial robusicity in Homo, I: Temporal rends and mechanical interpretation. Am. J. Phys. Antbropol. 91, 21-53

Ruff, C., Walker, A., Trinkaus, E., 1994. Postcranial robusticity in Homo, III Ontogeny. Am. J. Phys. Antbropol. 93, 35-54.

Sasaki, C., Suzuki, K., Mishima, H., Kozawa, Y., 2022. Age determination of Dederiyeh 1 Neanderthal child using enamel cross-swiations. In: Akazawa, T., Muhesen, S. (Eds.), Neanderthal Burials: Excavations of the Dederiyeh Cave, Afrin, Syria. International Research Center for Japanese Studies, Kyoto, pp. 263-270.
Scheuer, L., Black, S., 2000. Developmental Juvenile Osteology. Academic Press, San Diego.

Schwartz, J., Tattersall, I., 2002. The Human Fossil Record. Volume I: Terninology and Craniodental Morphology of Genus Homo (Europe). WileyLiss, New York

Senut, B., 1981. L'Humérus et ses articulations chez les hominidés PlioPléistocènes. CNRS, Paris.

Smith, P., 1989a. Dental evidence for phylogenetic relationships of Middle Paleolithic hominids. In: Otte, M. (Ed.), L'Homme de Néandertal, vol. 7. L'Exinction. Université de Liege, Liege, pp. 111-12.

Smith, P., 1989b. Dental ontogeny in fossil hominids. In: Giacobini, G. (Ed.), Hominidae: Proceedings of the Second International Congress of Human Paleontology. Jaca Book, Milán, pp. 347-350

Soler Mayor, B., 1996. Propuesta de Normalización en el Reconocimiento y Diagnosis de la Termoalteraciones de Rocas Carbonatadas en Contexto Arqueológico. Unpublished Ph.D. thesis, Universitat de València.

Tardieu, C., Trinkaus, E., 1994. Early ontogeny of the human femoral bicondylar angle. Am. J. Phys. Antbropol. 95, 183-195.

Tattersall, I., Schwartz, J., 1999. Hominids and hybrids: The place of Neanderthals in human evolution. Proc. Natl. Acad. Sci. U.S.A. 96, 7117-7119.

Telkkä, A., Palkama, A., Virtama, P., 1962. Estimation of stature from radiographs of long bones in children, part 1: children age from one to nine. Ann. Med. Exp. Biol. Femn. (Helsinki) 40, 91-96.

Thompson, J., Nelson, A., 2000. The place of Neandertals in the evolution of hominid patterns of growth and development. J. Hum. Evol. 38, 475-495.

Tillier, A.M., 1983. L'enfant Néanderthalien u Roc de Marsal (Campagne deBugue, Dordogne): Le squelette facial. Ann. Paléontologie 69, 137-149.

Tillier, A.M., 1992. The origins of modern humans in southwest Asia: ontogeneric aspects. In: Akazawa, T., Aoli, K., Kimura, T. (Eds.), The Evolution and Dispersal of Modern Humans in Asia. Hokusen-sha, Tokyo, pp. 16-28.

Tillier, A.M., 1999. Les Enfants Mousteriens de Qafzeh: Interpretation Phylogenerique et Paleoauxologique. CNRS Editions, Paris

Tillier, A.M., Arensburg, B., Vandermeersch, B., Chech, M., 2003. New human remains from Kebara Cave (Moumt Cannel). The place of the Kebara hominids in the Levantine Mousterian fossil record. Paleorient 29, 35-62.

Tomplins, R., 1996. Relative dental development of upper Pleistocene hominids compare to human population variation. Am. J. Phys. Antbropol. 99, $103-118$

Tompkins, R., Trinkaus, E., 1987. La Ferrasie 6 and the development of Neanderthal pubic morphology. Am. J. Phys. Anthropol. 73, 233-239.

Trinkaus, E., 1978. Les métatarsiens et les phalanges du pied des Néandertaliens de Spy. Bull. Inst. R. Sci. Nat. Belg. 51, 1-18.

Trinkaus, E., 1981. Neanderthal limb proporions and cold adaptation. In: Sringer, C. (Ed.), Aspects of Human Evolution. Taylor and Francis, London, pp. 187-219.

Trinkaus, E., 1983. The Shanidar Neandertals. Academic Press, New York.

Trinkaus, E., 1993. Femoral neck-shaft angles of the Qafzeh-Skhul early modem humans, and activity levels among immature Near Eastern Middle Paleolithic hominids. J. Hum. Evol. 25, 393-416.

Trinkaus, E., 1995. Neanderthal mortality patterns. J. Archaeol. Sci. 22, $131-142$.

Trinkaus, E., 2002. The cranial morphology. In: Zilhào, J., Trinkaus, E. (Eds.), Porrait of the Arrist as a Child. The Gravetian Human Skeleton from the Abrigo do Lagar Velho and its Archeological Context. Instituto Português de Arqueología, Lisboa, pp. 256-286.

Trinkaus, E., 2004. Eyasi 1 and the suprainiac fossa. Am. J. Phys. Antbropol. $124,28-32$.

Trinkaus, E., Churchill, S., 1988. Neandertal radial tuberosity orientation. Am J. Phys. Anthropol. 75, 15-21.

Trinkaus, E., Ruff, C., 1996. Early modern human remains from eastern Asia: the Yamashita-cho 1 inmature postcrania. J. Hum. Evol. 30, 299-314.

Trinkaus, E., Ruff, C., Esteves, F., Santos-Coelho, J., Silva, M., Mendonça, M., 2002a. The upper limb remains. In: Zilhão, J., Trinkaus, E. (Eds.), Portrait of the Artist as a Child. The Gravetian Human Skeleton from the Abrigo do Lagar Velho and its Archeological Context. Instituto Português de Arqueología, Lisboa, pp. 466-488.

Trinkaus, E., Ruff, C., Esteves, F., Santos-Coelho, J., Silva, M., Mendonça, M., 2002 b. The lower limb remains. In: Zilhão, J., Trinkaus, E. (Eds.), Portrait 
of the Artist as a Child. The Gravettian Human Skeleton from the Abrigo do Lagar Velho and its Archeological Context. Instituto Português de Arqueología, Lisboa, pp. 435-465.

Vallverdú, J., Allué, E., Bischoff, J., Cáceres, I., Carbonell, E., Cebrià, A., García-Antón, M., Huguet, R., Ibañez, N., Martínez, K., Pastó, I., Rosell, J., Saladié, P., Vaquero, M., 2005. Short human occupations in the Middle Palaeolithic level i of the Abric Romaní rock-shelter (Capellades, Barcelona, Spain). J. Hum. Evol. 48, 157-174.

Vandenneersch, B., Trinkaus, E., 1995. The postcranial remains of the Régourdou 1 Neandertal: the shoulder and ann remains. J. Hum. Evol. 28, 439-476.

Vaquero, M., 1999. In Middle Palaeolitbic: the evidence of the Abric Romaní (Capellades, Spain). Antiquity 73, 493-504.

Vaquero, M., Pastó, I., 2001. The definition of spatialunits in MiddlePalaeolithic sites: the hearth-related assemblages. J. Archaeol. Sci. 28, 1209-1220.

Villaverde, V., 1995. El Paleolítico en el País Valenciano: Novedades y breve síntesis. In: Actas de las Jornadas de Arqueología del Alfaç del Pi (Alicante). Consellería de Cultura, pp. 13-36.

Villaverde, V., Fumanal, M., 1990. Relations en le Paléolithique Moyen et le Paléolithique Supérieur dans le versant Méditerranéen espagnol. In: Paléolitbique Moyen Récent et Paléolithique Supérieur Ancien en
Europe. Mémoires du Musée de Prehistoire de l'Mle de France, vol. 3, pp. $177-183$

Villaverde, V., Marínez Valle, R., 1992. Economía y aprovechamiento del medio en el Paleolíico de la región central del Mediterráneo español. In: Moure, A. (Ed.), Elefantes, ciervos y ovicaprinos. Economía y aprovechamiento del medio de la Prehistoria de España y Portugal. Universidad de Cantabria, pp. 77-96.

Villaverde, V., Marínez Valle, R., Guillem, P., Fumanal, M., 1996. Mobility and the role of small game in the Middle Paleolithic of the central region of the Spanish Mediterranean: a comparison of Cova Negra with other Paleolithic deposits. In: Carbonell, E., Vaquero, M. (Eds.), The Last Neandertals, the First Anatomically Modern Humans: A Tale about the Human Diversity. Universitat Rovira I Virgili, Tarragona, pp. $267-288$.

Vlcek, E., 1973. Postcranial skeleton of a Neandertal child from Kiik-Koba, U.S.S.R. J. Hum. Evol. 2, 537-544.

Wolpoff, M., 198. Cranial remains of middle Pleistocene European hominids. J. Hum. Evol. 9, 339-358.

Wood, B., Engleman, C., 1988. Analysis of the dental morphology of PlioPleistocene hominids V. Maxillary postcanine tooth morphology. J. Anat. 161, 1-35. 